\title{
Seasonal variation in the phytoplankton community of a continental-shelf sea: the East China Sea
}

\author{
Shujin Guo ${ }^{1,2}$, Yuanyuan Feng ${ }^{1,2}$, Lei Wang ${ }^{1,2}$, Minhan Dai ${ }^{3}$, Zhiliang Liu ${ }^{4}$, Yan Bai ${ }^{5}$ \\ Jun $\operatorname{Sun}^{1,2, *}$ \\ ${ }^{1}$ College of Marine Science and Engineering, Tianjin University of Science and Technology, Tianjin 300457, PR China \\ ${ }^{2}$ Tianjin Key Laboratory of Marine Resources and Chemistry, Tianjin 300 457, PR China \\ ${ }^{3}$ State Key Laboratory of Marine Environmental Science, Xiamen University, Xiamen 361005, PR China \\ ${ }^{4}$ Institute of Oceanology, Chinese Academy of Science, Qingdao 266071, PR China \\ ${ }^{5}$ State Key Laboratory of Satellite Ocean Environment Dynamics, Second Institute of Oceanography, \\ State Oceanic Administration, Hangzhou 310012, PR China
}

\begin{abstract}
To better understand seasonal variation in phytoplankton community structure in the East China Sea (ECS), 4 research cruises were carried out between August 2009 and June 2011 over the continental shelf. Phytoplankton community structure and ambient seawater physicochemical parameters were examined. The phytoplankton community in the ECS was mainly composed of diatoms and dinoflagellates, with 242 taxa in 70 genera of diatoms and 104 taxa in 26 genera of dinoflagellates. Several species of Chlorophyta, Chrysophyta, and Cyanophyta were also observed. Chain-forming diatoms were the most dominant phytoplankton group throughout the year, except in spring when dinoflagellates dominated in coastal waters. Monsoon-induced turbulence played a significant role in regulating the dominance of dinoflagellates among seasons, with calm water favoring the growth of dinoflagellates and turbulent water inhibiting them. Phytoplankton abundance was always higher in coastal than offshore waters, mainly determined by nutrient availability. A Prorocentrum dentatum bloom and a Chaetoceros debilis bloom were observed in the Yangtze River estuary in spring 2011 and fall 2010, respectively. The blooms differed greatly in community diversity and cell abundance distribution, potentially affecting organic carbon export. In general, 3 different hydrographic water systems (coastal water, shelf mixed water, and Kuroshio water) were identified from a temperature-salinity plot of the ECS, and phytoplankton abundance showed spatially and temporally different distribution patterns in these 3 water systems. The nutrient N:P ratio, but not the Si:N ratio, played a significant role in regulating the phytoplankton community structure and the formation of the spring coastal dinoflagellate bloom in the ECS.
\end{abstract}

KEY WORDS: Phytoplankton $\cdot$ Community structure $\cdot$ Seasonal variation $\cdot$ Controlling factors East China Sea $\cdot$ Yangtze River

\section{INTRODUCTION}

As primary producers in the ocean, phytoplankton play significant roles in regulating the marine ecosystem and global carbon cycle by photosynthesis and thus providing energy for other organisms (Falkowski \& Woodhead 1992). Phytoplankton cells concentrate and bloom on continental shelves, where elevated amounts of nutrients are provided by anthropogenic input and physical upwelling (Gasol et al. 1997). Due to the strong interaction between land and ocean, the physical and chemical environment of continental shelves tends to be highly variable both spatially and temporally, which greatly contributes to the complexity of phytoplankton communities in these areas (Zhu et al. 2009). 
The East China Sea (ECS), the largest marginal sea in the western Pacific, has a broad continental shelf area of about $500000 \mathrm{~km}^{2}$ (Gong et al. 2003). It borders on the coast of China in the west and the Kuroshio Current in the east. Abundant discharge from the Yangtze River carries a tremendous amount of fresh water with low temperature and salinity into the ECS and forms the coastal water, while the offshore oligotrophic Kuroshio water is characterized by high temperature and salinity (Chao 1990). Coastal water and offshore Kuroshio water meet at the continental shelf of the ECS and form the shelf mixed water (Yanagi \& Takahashi 1993), including several different hydrographic waters such as the nutrientenriched Yangtze River Diluted Water (YDW), warm and oligotrophic Taiwan Warm Current Water (TWCW), Kuroshio Water (KW), and the Yellow Sea Cold Water (YSCW), among others (Gong et al. 1996). Annually, large amounts of nutrients are supplied into the ECS by runoff from the Yangtze River (Edmond et al. 1985, Shen et al. 2008) and upwelling of TWCW along the Chinese coast (Lee Chen 2000), and a significant amount of nutrients is supplied by the persistent upwelling of Kuroshio Subsurface Water (KSW) in the southern ECS northeast of Taiwan (Gong et al. 1996). With such fertile hydrographic conditions, the ECS is famous for its high biological productivity and is considered a sink of atmospheric $\mathrm{CO}_{2}$ (Chen \& Wang 1999).

Due to the shallow water depth and large seasonal variation of both monsoons and heat transfer through the sea surface, water dynamics in the ECS vary greatly among seasons, which makes the hydrographic conditions in this area very complex (Yanagi \& Takahashi 1993). Several studies of the phytoplankton community have been conducted in the ECS, mostly in the Yangtze River estuary and adjacent waters. Three different phytoplankton communities in the Yangtze River estuary have been identified according to the salinity gradient: the estuarine community, the Yangtze River diluted community, and the high salinity community (Wang 2002, Zhu et al. 2003). Diatoms and dinoflagellates are the most dominant groups in this area (Guo \& Yang 1992, Gao \& Song 2005, Luan et al. 2008, He et al. 2009, Zhao et al. 2010), and Prorocentrum dentatum and Skeletonema costatum are the most frequent bloom-forming algae in spring and summer (Tang et al. 2006). Some previous studies were carried out on the continental shelf area of the ECS. Furuya et al. (1996) studied the phytoplankton community along a cross-shelf transect ('PN') in the ECS in winter and identified 2 distinct phytoplankton communities: a shelf community char- acterized by high abundance of diatoms and an oceanic community with numerical dominance of coccolithophorids and diatoms. Furuya et al. (2003) also studied the phytoplankton community along transect PN with the HPLC method, and found that diatoms dominated the shelf water with high biomass, while pico- and nano-sized phytoplankton dominated off the shelf water with low biomass. Chiang et al. (1999, 2004) studied the relationship between diatoms and water types in the ECS and found that the distribution of diatom communities matched that of water types. Several other studies on the phytoplankton community in the ECS were based upon net-sampling methods (Li \& Mao 1985, Qian \& Chen 1986, Guo \& Yang 1992, Lin 1995) and provide abundant historical data on the phytoplankton community in this area. However, most of the above studies were carried out in a limited area of the ECS, or were only conducted over 1 season. Studies of seasonal variation in the phytoplankton community over the whole continental shelf of the ECS are still limited, and the relationships between environmental parameters and the phytoplankton community in this area remain unclear.

Four seasonal cruises were carried out in the ECS during 2009 and 2011 to study the phytoplankton community, including the seasonal variation in species composition and cell abundance distribution. Environmental parameters controlling seasonal variation in the phytoplankton community are discussed, which will provide insight into the relationships among physical, chemical, and biological elements in this area.

\section{MATERIALS AND METHODS}

\section{Cruises}

Four cruises were conducted in the ECS: 18 to 29 August 2009, 23 December to 4 January 2010, 11 November to 9 December 2010, and 30 May to 8 June 2011, representing summer, winter, fall, and spring, respectively. The study covered the entire continental shelf area of the ECS (Fig. 1). In spring, the study area was constricted to the shelf shallower than $100 \mathrm{~m}$. Most of the stations were positioned along 3 cross-shelf transects during the 4 cruises.

\section{Sampling and analysis methods}

Water samples were collected by a SeaBird CTD (SBE 9/11 plus) equipped with 12 l Go-Flo bottles, 


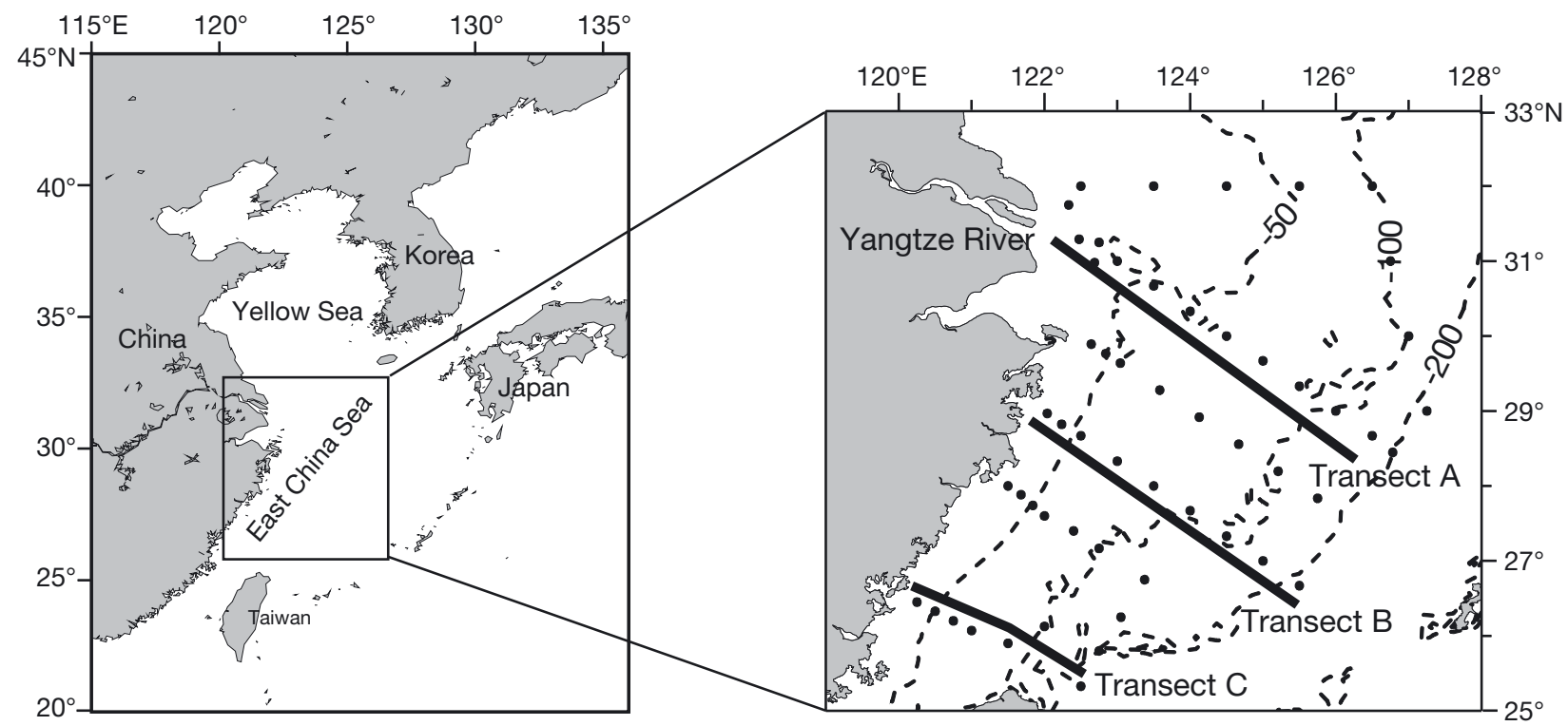

Fig. 1. Location of sampling stations (black dots) during 4 cruises in the East China Sea. Three main transects (A-C) across the continental shelf are highlighted (see Figs. 4 \& 7). Dashed lines are depth contours (in m)

and temperature, salinity, and pressure were recorded at the same time. Downwelling scalar irradiance (photosynthetically active radiation, PAR) was measured by an RBR (XRX-620) sensor. The PAR data were not measured in summer. Water samples were collected at 3 to 9 different depths at each station from the surface $(2 \mathrm{~m})$ to the bottom, evenly distributed throughout the water column.

Samples for nutrient analysis were filtered using $0.45 \mu \mathrm{m}$ cellulose acetate membrane filters for sampling depths $<200 \mathrm{~m}$, and no filtration was applied for sampling depths $>200 \mathrm{~m}$. The nutrient samples were analyzed immediately after sampling or were refrigerated at $4^{\circ} \mathrm{C}$ and analyzed within $24 \mathrm{~h}$ upon sampling. Nutrient concentrations including $\mathrm{NO}_{3}-\mathrm{N}$, $\mathrm{NO}_{2}-\mathrm{N}, \mathrm{PO}_{4}-\mathrm{P}$, and $\mathrm{SiO}_{3}-\mathrm{Si}$ were examined with a Technicon AA3 Auto-Analyzer (Bran+Luebbe) onboard according to classical colorimetric methods. Dissolved inorganic nitrogen (DIN) was analyzed using the copper-cadmium column reduction method (Pai et al. 2001), and dissolved inorganic phosphorus (DIP) and $\mathrm{Si}(\mathrm{OH})_{4}$ were measured using typical spectrophotometric methods (Dai et al. 2008). Water samples for chlorophyll a ( $\mathrm{chl}$ a) analysis were filtered through GF/F filters (Whatman, $25 \mathrm{~mm}$ ) and stored at $-20^{\circ} \mathrm{C}$. The chl a retained on the GF/F filters was determined fluorometrically (Welschmeyer 1994). Samples for phytoplankton analysis were fixed with $2 \%$ buffered formalin and stored in darkness. After returning to the laboratory, phytoplankton cells were concentrated with $100 \mathrm{ml}$ settlement columns for 24 to $48 \mathrm{~h}$, and then identified and counted with an inverted Olympus microscope at 400× magnification according to the methodology described by Utermöhl (1958). The size limit of resolution for this analysis was $\sim 5 \mu \mathrm{m}$.

\section{Data analysis}

The dominance of phytoplankton species is described by the dominance index $(Y): Y=\left(n_{i} / N\right) \times f_{i}$, where $n_{i}$ is the sum of cell abundance for species $i$ in all samples; $N$ is the sum of cell abundance for all species; and $f_{i}$ is the frequency of occurrence for species $i$ in all samples. Community diversity is described by the Shannon-Wiener diversity index $\left(H^{\prime}\right)$, following the formulation given by Sun \& Liu (2004). Turbulence intensity is expressed by the stratification index (Simpson \& Hunter 1974) and is calculated as the density difference divided by depth difference between surface and bottom layers (or $100 \mathrm{~m}$ for water depth deeper than $100 \mathrm{~m}$ ). Seawater density was calculated from temperature, salinity, and pressure. The euphotic depth was defined as the depth of $1 \%$ surface light penetration.

SPSS14.0 was applied to carry out a Pearson correlation analysis between phytoplankton abundance and environmental parameters both at the surface and at all water depths. A commercial software multivariate statistical package was applied to carry out the canonical correspondence analysis (CCA) between the dominant species abundances and environmental parameters. 


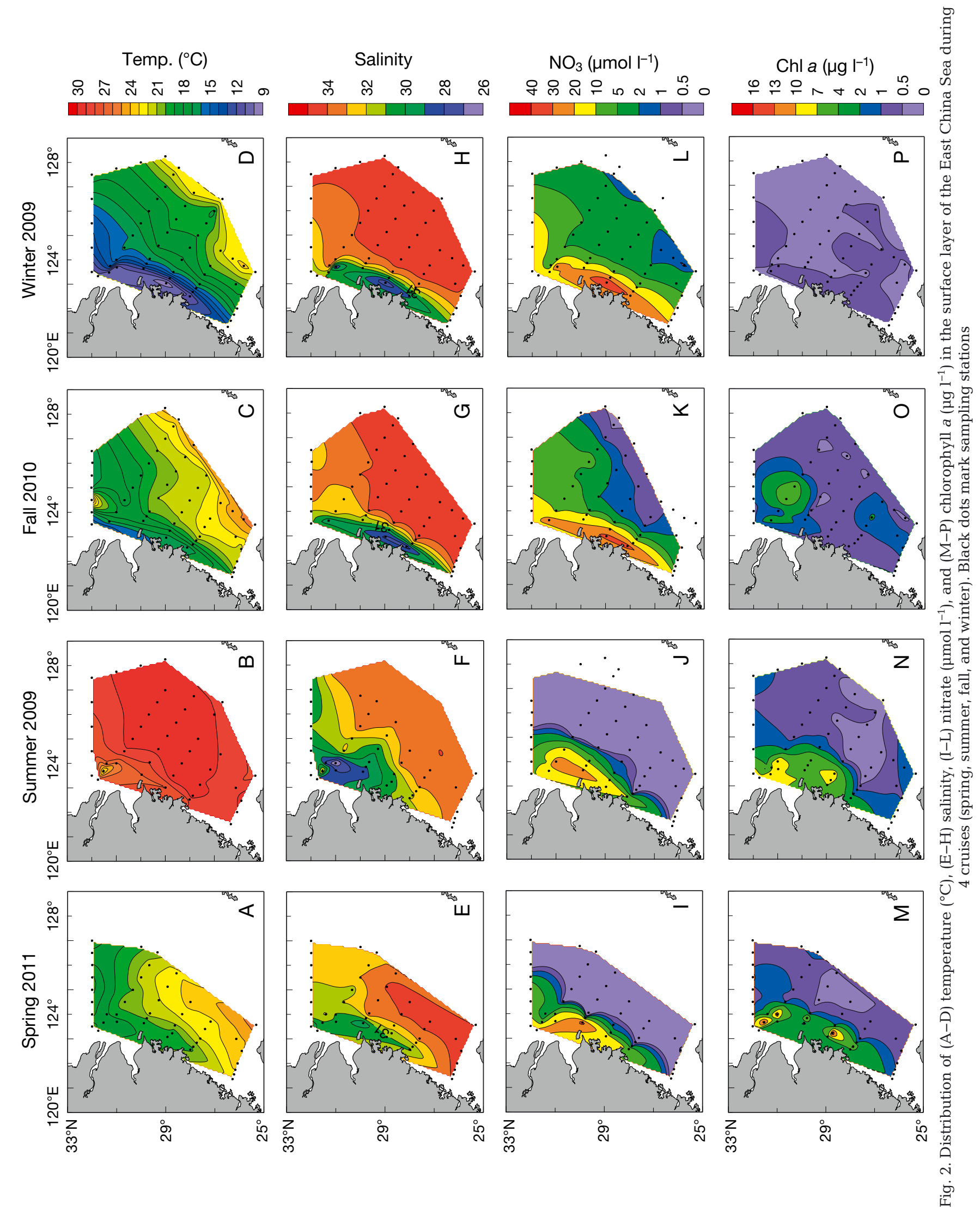




\section{RESULTS}

\section{Hydrographic conditions}

The distributions of temperature, salinity, nitrate, and chl a concentration in the surface water are shown in Fig. 2A-P. The coastal water influenced by YDW was characterized by low temperature and salinity and high nitrate and chl a concentrations. Conversely, high temperature and salinity and low nitrate and chl a concentrations characterized the offshore KW. Active mixing of these 2 waters resulted in the intermediate shelf mixed water (Fig. 3). Sea surface temperature (SST) was highest in summer, varying between 22.1 and $30.1^{\circ} \mathrm{C}$, and lowest in winter, varying between 9.2 and $23.5^{\circ} \mathrm{C}$. SST in spring and fall showed no obvious difference, varying from 16.6 to $25.5^{\circ} \mathrm{C}$ and 13.8 to $26.4^{\circ} \mathrm{C}$, respectively. In summer, besides the cold water off the mouth of the Yangtze River, a small cold eddy appeared northeast of Taiwan, indicating the upwelling of KSW there (Fig. 2B). Sea surface salinity (SSS) was lowest in summer due to the high runoff of the Yangtze River and varied between 25.47 and 34.04. In spring, fall, and winter, SSS showed no obvious difference among the 3 seasons. According to the SSS, the mainstream of the YDW flowed southwest along the mainland coast in spring, fall, and winter, and an offshore detachment of the YDW in a northeasterly direction was observed in summer (Fig. 2E-H). The nitrate concentration was higher in coastal water $\left(>10 \mu \mathrm{mol} \mathrm{l}^{-1}\right)$ than in offshore water in all 4 seasons. No obvious seasonal variation was observed for nitrate concentration in coastal water, while in offshore water, the nitrate concentrations in spring and summer $\left(<0.1 \mu \mathrm{mol} \mathrm{l}^{-1}\right)$ were lower than in fall and winter. Surface chl a concentration in the coastal water exceeded $4 \mu \mathrm{g} \mathrm{l}^{-1}$ in spring and summer, and 2 stations (PN08 and PN09) adjacent to the Yangtze River estuary showed high chl a values $\left(>4 \mu \mathrm{g} \mathrm{l}^{-1}\right)$ in fall (Fig. 2O). In winter, chl a concentrations at most stations in the ECS were below $1 \mathrm{\mu g} \mathrm{l}^{-1}$. In summer and fall, a patch of chl a concentration exceeding $1 \mathrm{\mu g} \mathrm{l}^{-1}$ was observed in the southern part of the ECS northeast of Taiwan.

The vertical distributions of temperature, salinity, nitrate, and chl a concentration along transect $\mathrm{A}$ are shown in Fig. 4A-P. The water column was stratified due to high surface temperature in spring and summer (Fig. 4A,B,E,F). In fall and winter, however, the water column was homogeneously mixed except the stratified inshore water under the influence of YDW in fall (Fig. 4C,D, $\mathrm{G}, \mathrm{H})$. The nitrate concentration was higher in coastal water than in offshore water in all 4 seasons (Fig. 4IL). A nitracline formed in spring and summer in mid-shelf and offshore waters, with nitrate concentrations not exceeding $0.5 \mu \mathrm{mol} \mathrm{l}^{-1}$ in the water above the nitracline. In fall and winter, no nitracline formed due to the strong water mixing. High $\mathrm{chl} a$ concentrations $\left(>7 \mu \mathrm{g} \mathrm{l}^{-1}\right.$ ) were observed in the estuary area in spring and summer. In fall, high chl a concentrations $\left(>5 \mu \mathrm{g} \mathrm{l}^{-1}\right.$ ) appeared at Stns PN09 and PN08 on the mid-shelf adjacent to the Yangtze River estuary. $\mathrm{Chl}$ a concentrations in winter were lower than in the other 3 seasons

(Fig. 4M-P).
Fig. 3. Temperature-salinity (T-S) relationship of sea water during 4 cruises (spring, summer, fall, and winter) in the East China Sea. A salinity of $\sim 31 \mathrm{psu}$ characterizes the coastal water system (dashed blue line), and the pink solid line represents the mean T-S characteristic of the Kuroshio water system. Density $\left(\sigma_{\theta}\right)$ contour lines are also given 

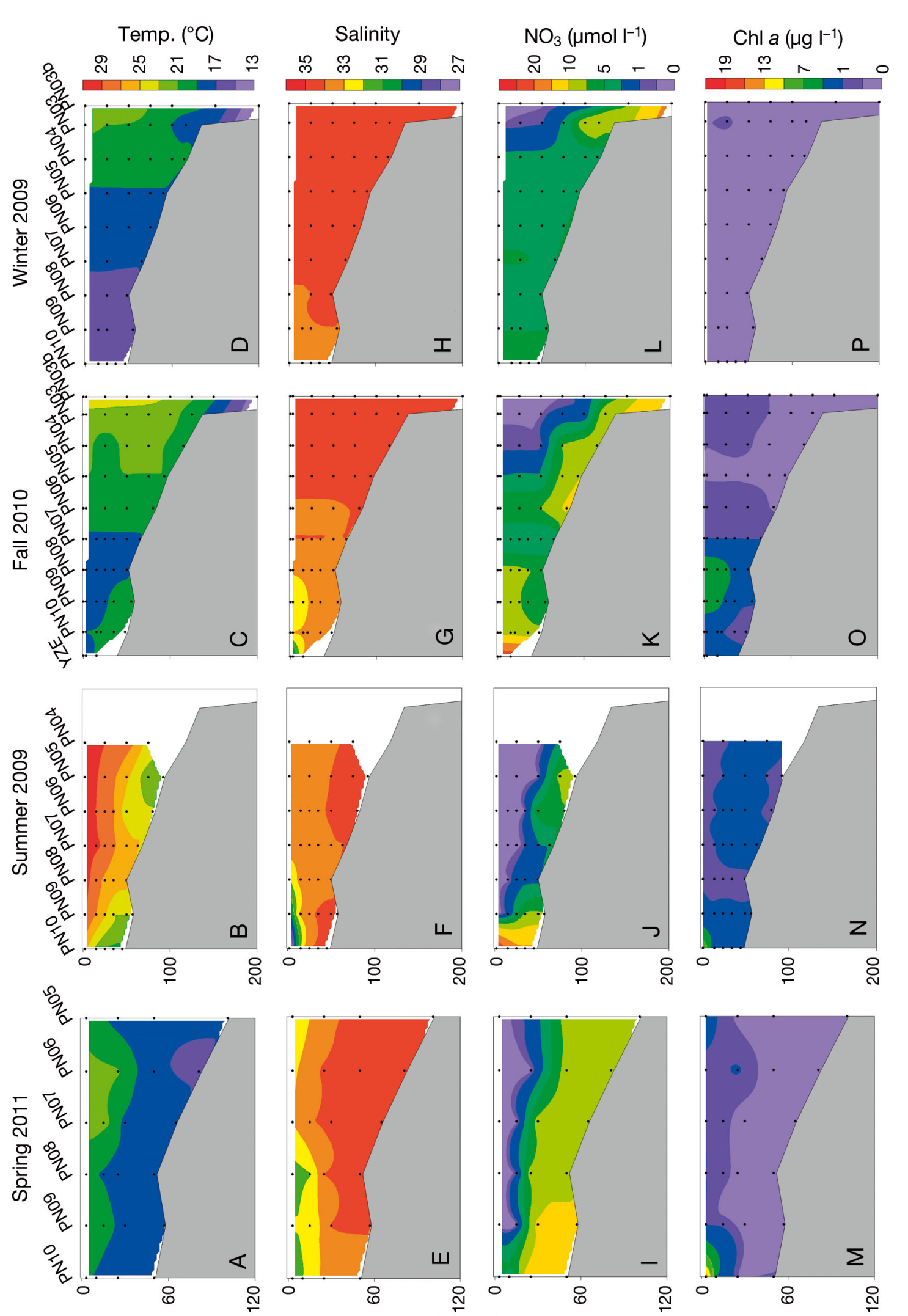

(w) पұdə0

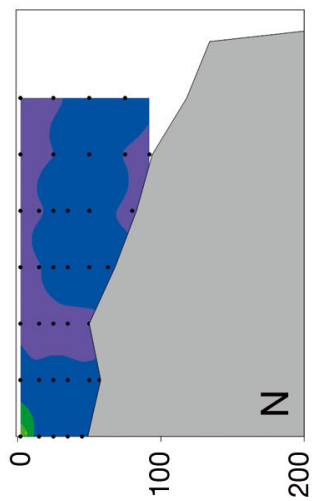

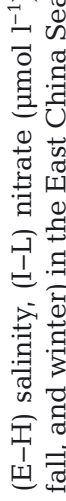

บิ

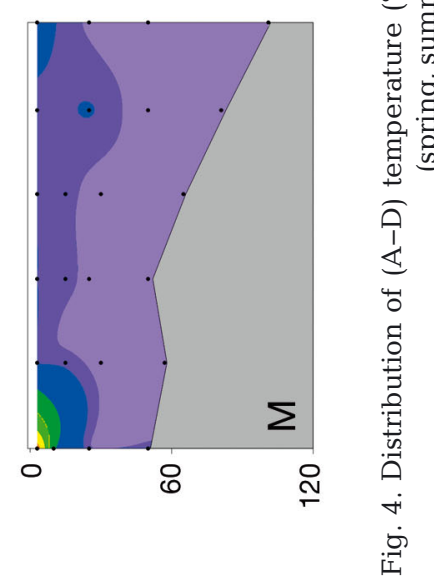


Table 1. Taxonomic composition of phytoplankton sampled during 4 cruises (spring, summer, fall, and winter) in the East China Sea. -: not observed, G: number of genera, S: number of species

\begin{tabular}{|c|c|c|c|c|c|c|c|c|c|c|c|c|}
\hline \multirow[t]{2}{*}{ Season } & \multicolumn{2}{|c|}{ Diatom } & \multicolumn{2}{|c|}{ Dinoflagellate } & \multicolumn{2}{|c|}{ Chrysophyta } & \multicolumn{2}{|c|}{ Chlorophyta } & \multicolumn{2}{|c|}{ Cyanophyta } & \multicolumn{2}{|c|}{ Total } \\
\hline & $\mathrm{G}$ & S & G & $\mathrm{S}$ & G & $\mathrm{S}$ & G & $\mathrm{S}$ & G & $\mathrm{S}$ & $\mathrm{G}$ & $\mathrm{S}$ \\
\hline Spring & 51 & 135 & 12 & 39 & 4 & 5 & - & - & 1 & 2 & 68 & 181 \\
\hline Summer & 55 & 136 & 11 & 67 & 2 & 4 & 2 & 2 & 1 & 2 & 71 & 211 \\
\hline Fall & 55 & 167 & 20 & 50 & 3 & 6 & - & - & 1 & 2 & 79 & 225 \\
\hline Winter & 48 & 115 & 21 & 51 & 1 & 3 & - & - & 1 & 2 & 71 & 171 \\
\hline Total & 70 & 241 & 26 & 104 & 4 & 7 & 2 & 2 & 1 & 1 & 103 & 356 \\
\hline
\end{tabular}

\section{Species composition}

In total, 356 taxa were identified during the 4 cruises in the ECS, belonging to 5 phyla and 103 genera. Diatoms and dinoflagellates were the dominant groups (Table 1). Most of these species were neritic or cosmopolitan, and some brackish species such as Skeletonema sp., Melosira granulata, and Scrippsiella trochoidea also appeared in the coastal water due to the influence of YDW. In the southern part of the continental shelf, some warm-water species such as Planktoniella sol and Bellerochea malleus were observed due to the influence of TWCW. The most species-rich genera in the ECS were Chaetoceros, Coscinodiscus, Rhizosolenia, and Pleurosigma for diatoms, and Protoperidinium, Ceratium, Gymnodinium, and Prorocentrum for dinoflagellates.

The dominant species in the ECS were mostly chain-forming diatoms, with Pseudo-nitzschia delicatissima, Thalassionema nitzschioides, and Paralia sulcata being the most common dominant species in the 4 seasons (Table 2). Dinoflagellates were dominant in spring and summer only. In spring, the most dominant dinoflagellate species was Prorocentrum dentatum (renamed as Prorocentrum donghainese $\mathrm{Lu}_{i} \mathrm{Lu}$ et al. 2005). Other species such as $S$. trochoidea and Gymnodinium lohmanni were also relatively dominant. In summer, dominant species belonged to diatoms and dinoflagellates. In fall and winter, no dinoflagellates were among the 15 most dominant species. A preliminary analysis of appearance frequency $\left(f_{i}\right)$ of various species was conducted to explore the difference in species composition among seasons, and the species with frequency $\left(f_{i}\right)$ exceeding $5 \%$ in all 4 cruises are listed in Table 3 . The frequency of most dinoflagellate species decreased in fall and winter when compared to spring and summer, especially for species in the genera Ceratium, Protoperidinium, and Gymnodinium, similar to the seasonal variation in dominant species composition (Table 2).

Table 2. Top 15 dominant phytoplankton species sampled during 4 cruises (spring, summer, fall, and winter) in the East China Sea

\begin{tabular}{|c|c|c|c|c|}
\hline & Spring 2011 & Summer 2009 & Fall 2010 & Winter 2009 \\
\hline 1 & Prorocentrum dentatum ${ }^{\mathrm{A}, \mathrm{a}}$ & Thalassionema nitzschioides ${ }^{\mathrm{B}, \mathrm{b}}$ & Chaetoceros debilis ${ }^{\mathrm{B}, \mathrm{b}}$ & Paralia sulcata ${ }^{\mathrm{B}, \mathrm{b}}$ \\
\hline 2 & Paralia sulcata ${ }^{\mathrm{B}, \mathrm{b}}$ & Pseudo-nitzschia pungens ${ }^{\mathrm{B}, \mathrm{b}}$ & Chaetoceros curvisetus ${ }^{\mathrm{B}, \mathrm{b}}$ & Thalassionema nitzschioides ${ }^{\mathrm{B}, \mathrm{b}}$ \\
\hline 3 & Pseudo-nitzschia delicatissima ${ }^{\mathrm{B}, \mathrm{b}}$ & Thalassionema frauenfeldii ${ }^{\mathrm{B}, \mathrm{b}}$ & Pseudo-nitzschia delicatissima ${ }^{\mathrm{B}, \mathrm{b}}$ & Pseudo-nitzschia delicatissima $^{\mathrm{B}, \mathrm{b}}$ \\
\hline 4 & Thalassionema nitzschioides ${ }^{\mathrm{B}, \mathrm{b}}$ & Skeletonema sp. ${ }^{\mathrm{B}, \mathrm{b}}$ & Leptocylindrus danicus ${ }^{\mathrm{B}, \mathrm{b}}$ & Thalassiosira angulata ${ }^{\mathrm{B}, \mathrm{b}}$ \\
\hline 5 & Gymnodinium sp. , a $^{\mathrm{A}}$ & Scrippsiella trochoide $a^{\mathrm{A}, \mathrm{a}}$ & Rhizosolenia delicatula ${ }^{\mathrm{B}, \mathrm{b}}$ & Thalassiosira subtilis $^{\mathrm{B}, \mathrm{b}, \mathrm{c}}$ \\
\hline 6 & Guinardia stolterforthii sp. ${ }^{\mathrm{B}, \mathrm{b}}$ & Pseudo-nitzschia delicatissima ${ }^{\mathrm{B}, \mathrm{b}}$ & Pseudo-nitzschia pungens ${ }^{\mathrm{B}, \mathrm{b}}$ & Coscinodiscus oculus-iridis ${ }^{\mathrm{B}, \mathrm{a}}$ \\
\hline 7 & Skeletonema sp. & Gymnodinium sp. ${ }^{\mathrm{A}, \mathrm{a}}$ & Thalassionema nitzschioides ${ }^{\mathrm{B}, \mathrm{b}}$ & Chaetoceros affinis ${ }^{\mathrm{B}, \mathrm{b}}$ \\
\hline 8 & Nitzschia sp. ${ }^{\mathrm{B}, \mathrm{a}}$ & Prorocentrum minimum ${ }^{\mathrm{A}, \mathrm{a}}$ & Skeletonema sp. ${ }^{\mathrm{B}, \mathrm{b}}$ & Thalassionema frauenfeldii ${ }^{\mathrm{B}, \mathrm{b}}$ \\
\hline 9 & Thalassiosira sp. , b $^{2}$ & Thalassiothrix longissima ${ }^{\mathrm{B}, \mathrm{b}}$ & Paralia sulcata ${ }^{\mathrm{B}, \mathrm{b}}$ & Entomoneis alata $^{\mathrm{B}, \mathrm{a}}$ \\
\hline 10 & Scrippsiella trochoidea ${ }^{\mathrm{A}, \mathrm{a}}$ & Detonula pumila ${ }^{\mathrm{B}, \mathrm{b}}$ & Thalassiosira sp. ${ }^{\mathrm{B}, \mathrm{b}}$ & Pleurosigma affine ${ }^{\mathrm{B}, \mathrm{a}}$ \\
\hline 11 & Gymnodinium lohmanni $^{\mathrm{A}, \mathrm{a}}$ & Trichodesmium thiebaultii ${ }^{\mathrm{C}, \mathrm{c}}$ & Detonula pumila ${ }^{\mathrm{B}, \mathrm{b}}$ & Trichodesmium thiebaultii ${ }^{\mathrm{C}, \mathrm{c}}$ \\
\hline 12 & Prorocentrum triestinum ${ }^{\mathrm{A}, \mathrm{a}}$ & Chaetoceros curvisetus $^{\mathrm{B}, \mathrm{b}}$ & Nitzschia sp., a & Corethron pelagicum ${ }^{\mathrm{B}, \mathrm{a}}$ \\
\hline 13 & Chaetoceros sp. ${ }^{\mathrm{B}, \mathrm{b}}$ & Protoperidinium sp. ${ }^{\mathrm{A}, \mathrm{a}}$ & Chaetoceros decipiens $^{\mathrm{B}, \mathrm{b}}$ & Detonula pumila ${ }^{\mathrm{B}, \mathrm{b}}$ \\
\hline 14 & Trichodesmium thiebaultii ${ }^{\mathrm{C}, \mathrm{c}}$ & Chaetoceros lorenzianus $^{\mathrm{B}, \mathrm{b}}$ & Thalassiosira pacifica $^{\mathrm{B}, \mathrm{b}}$ & Donkinia recta ${ }^{\mathrm{B}, \mathrm{a}}$ \\
\hline 15 & Noctiluca scintillans ${ }^{\mathrm{A}, \mathrm{a}}$ & Noctiluca scintillans ${ }^{\mathrm{A}, \mathrm{a}}$ & Chaetoceros castracanei ${ }^{\mathrm{B}, \mathrm{b}}$ & Coscinodiscus bipartitus $^{\mathrm{B}, \mathrm{a}}$ \\
\hline
\end{tabular}


Table 3. Appearance frequency $\left(f_{i}\right)$ of different phytoplankton species sampled during 4 cruises (spring, summer, fall, and winter) in the East China Sea. The $f_{i}$ of species outlined below were $>5 \%$ in all 4 seasons. $f_{i}$ values are marked as follows. +: 5 to $<10 \%$; ++: 10 to $<20 \%$; +++: 20 to $<30 \%$; ++++: 30 to $<40 \%$; +++++: 40 to $<50 \%$; ++++++: 50 to $<60 \%$; +++++++: 60 to $<70 \%$

\section{Horizontal distribution of phytoplankton}

Phytoplankton abundances in the ECS ranged from $0.04 \times 10^{3}$ to $2.85 \times 10^{6}$ cells $^{-1}$ (mean $1.19 \times 10^{5}$ cells $\mathrm{l}^{-1}$ ) in spring, $0.1 \times 10^{3}$ to $8.01 \times 10^{5}$ cells l$^{-1}$

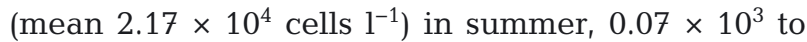
$8.36 \times 10^{6}$ cells l$^{-1}$ (mean $8.71 \times 10^{5}$ cells l$^{-1}$ ) in fall, and $0.04 \times 10^{3}$ to $7.13 \times 10^{4}$ cells l$^{-1}$ (mean $7.30 \times 10^{3}$ cells $\mathrm{l}^{-1}$ ) in winter. Horizontal distributions of phytoplankton abundance (surface and depth-integrated) are shown in Figs. 5 \& 6. Diatoms dominated the distribution pattern of phytoplankton abundance in the surface layer, except in spring when dinoflagellates dominated in the Yangtze River estuary and adjacent water (Fig. 5I). High abundances were always observed in estuary and coastal waters, and decreased offshore. In summer and fall, elevated abundances were observed in the area northeast of Taiwan, with dominant species being chain-forming diatoms such as Pseudo-nitzschia spp. and T. nitzschioides (Fig. 5). In winter, high abundances appeared in the northern part of the ECS, and P. sulcata was the most dominant species (Fig. 5D). A spring P. dentatum dinoflagellate bloom and a fall Chaetoceros debilis diatom bloom were observed in the Yangtze River estuary (Fig. 5I and G, respectively), both characterized by cell abundances exceeding $10^{6}$ cells $^{-1}$ in the surface layer (Table 4). In spring, $P$. dentatum contributed more than $99 \%$ of surface cell abundance at stations where blooms occurred. In fall, diatoms dominated the phytoplankton group at bloom stations, and the dominant species were C. debilis, Skeletonema sp., Rhizosolenia delicatula, Pseudo-nitzschia pungens, and Leptocylindrus danicus.

The depth-integrated $(200 \mathrm{~m})$ abundances of phytoplankton (Fig. 6) ranged from $0.05 \times 10^{9}$ to 2.46 $\times 10^{10}$ cells m$^{-2}$ (mean $3.20 \times 10^{9}$ cells m$^{-2}$ ) in spring, $0.03 \times 10^{9}$ to $1.05 \times 10^{10}$ cells m$^{-2}$ (mean $1.00 \times 10^{9}$ cells $\mathrm{m}^{-2}$ ) in summer, $0.02 \times 10^{9}$ to $1.83 \times 10^{12}$ cells $\mathrm{m}^{-2}$ (mean $7.20 \times 10^{10}$ cells m$\left.{ }^{-2}\right)$ in fall, and $0.03 \times 10^{9}$ to $1.80 \times 10^{9}$ cells m$^{-2}$ (mean $0.40 \times 10^{9}$ cells m$^{-2}$ ) in winter. Distribution of integrated abundances of phytoplankton was similar to that in the surface layer. Diatoms dominated the distribution pattern, except in spring, when dinoflagellates contributed more in the coastal water influenced by YDW (Fig. 6).

Species Spring Summer Fall Winter

\section{Diatoms}

Centric

Bacteriastrum hyalinum

Biddulphia spp.

Chaetoceros sp.

Chaetoceros curvisetus

Chaetoceros lorenzianus

Corethron hystrix

Coscinodiscus spp.

Coscinodiscus bipartitus

Detonula pumila

Ditylum brightwellii

Eucampia zodiacus

Guinardia stolterforthii

Hemiaulus spp.

Leptocylindrus danicus

Paralia sulcata

Proboscia alata

Rhizosolenia setigera

Rhizosolenia styliformis

Skeletonema sp.

Thalassiosira eccentrica

Thalassiosira sp.

Pennate

Diploneis bombus

Donkinia recta

Navicula spp.

Nitzschia longissima

Nitzschia sp.

Nitzschia lorenziana

Nitzschia sigma var.

intermedium

Pleurosigma sp.

Pleurosigma affine

Pleurosigma angulatum

Pseudo-nitzschia delicatissima

Pseudo-nitzschia pungens

Thalassionema frauenfeldii

Thalassionema nitzschioides

\section{Dinoflagellates}

Thecate

Ceratium breve

Ceratium furca

Ceratium fusus

Ceratium kofoidii

Ceratium tripos

Gyrodinium spirale

Oxytoxum sp.

Protoperidinium sp.

Protoperidinium bipes

Protoperidinium depressum

Protoperidinium ovum

Scrippsiella trochoidea

Non-thecate

Dinophysis acuminata

Dinophysis caudata

Gymnodinium sp.

Gymnodinium lohmanni

Noctiluca scintillans

Prorocentrum dentatum

Prorocentrum micans

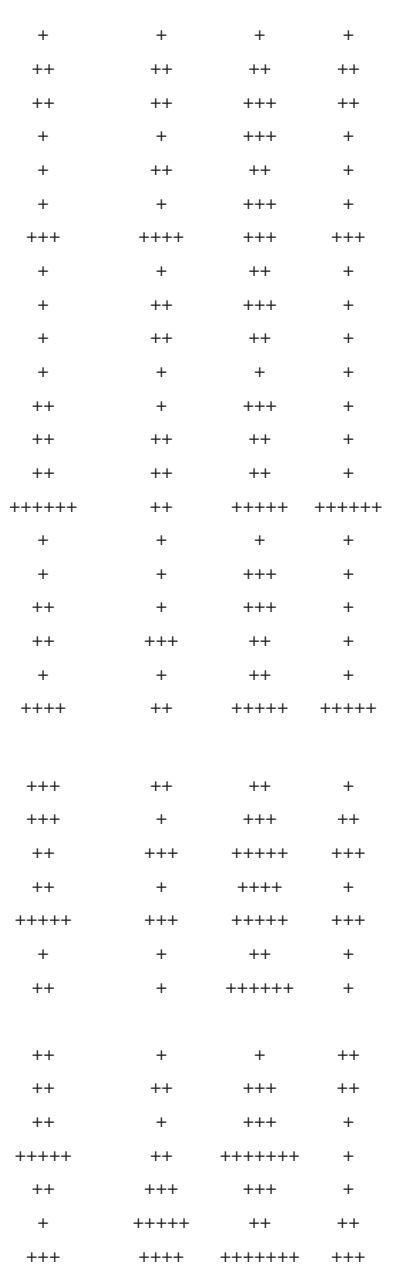

$\begin{array}{cccc}+ & + & + & + \\ + & ++ & + & + \\ + & ++ & ++ & + \\ + & + & + & + \\ + & + & + & + \\ + & ++ & + & + \\ + & + & + & + \\ + & +++ & + & + \\ ++ & ++ & + & + \\ + & + & + & + \\ + & + & + & + \\ +++ & +++ & + & + \\ & & & \\ + & + & + & + \\ + & ++ & + & + \\ ++ & +++++ & + & + \\ ++ & ++ & ++ & + \\ ++ & ++ & + & + \\ +++ & ++ & + & + \\ + & ++ & + & + \\ +\end{array}$ 


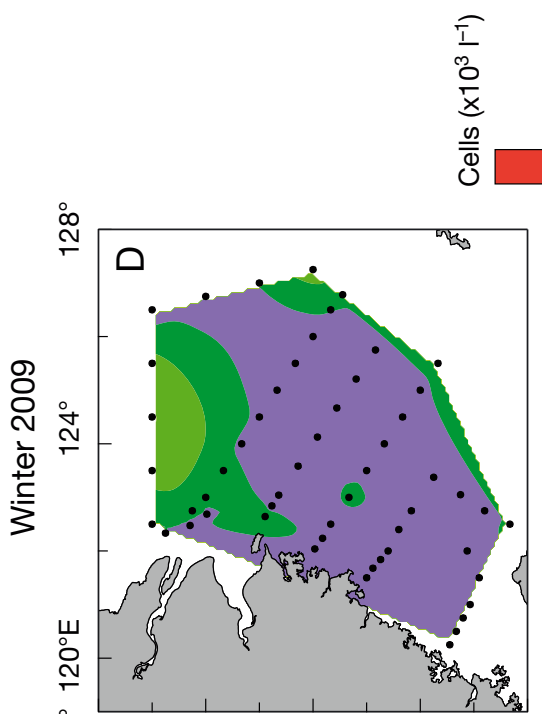

囬 \&
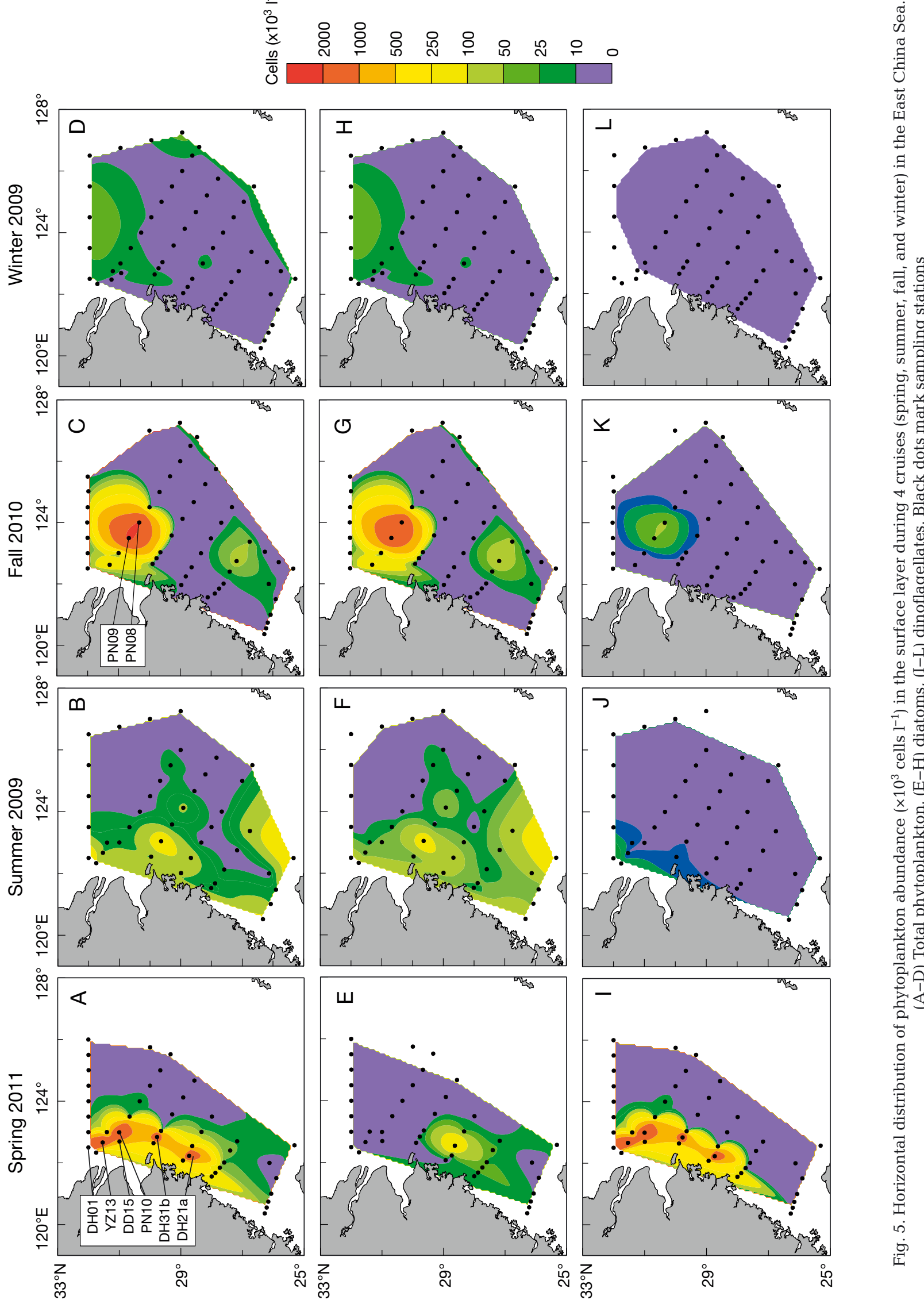
Tै

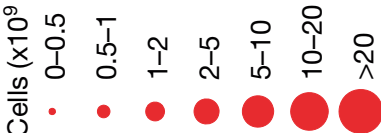
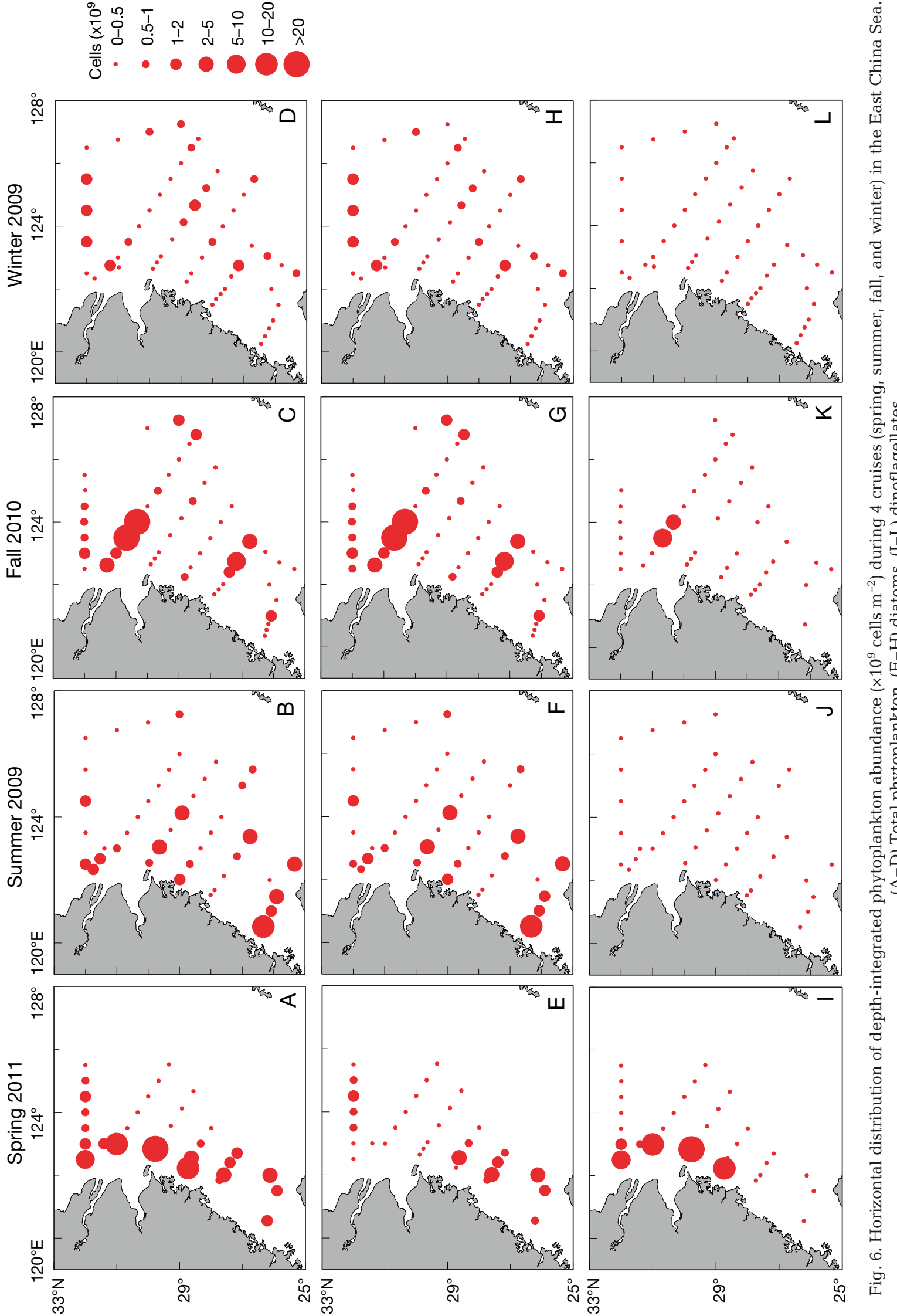
Table 4. Cell abundances $\left(\times 10^{3}\right.$ cells $\left.\mathrm{l}^{-1}\right)$ and environmental parameters in the surface layer of bloom stations in spring and fall in the East China Sea. -: below the detection limit. Phyto: phytoplankton, Dino: dinoflagellates, Species 1: bloom-causing species, $H^{\prime}$ : Shannon-Wiener diversity index, T: temperature, S: salinity. Units are $\mu \mathrm{mol} \mathrm{l}^{-1}$ for nutrients

\begin{tabular}{|c|c|c|c|c|c|c|c|c|c|c|c|}
\hline Station & Phyto & Diatoms & Dino & Species 1 & $H^{\prime}$ & $\mathrm{T}\left({ }^{\circ} \mathrm{C}\right)$ & $\mathrm{S}$ & $\mathrm{NO}_{3}-\mathrm{N}$ & $\mathrm{NO}_{2}-\mathrm{N}$ & $\mathrm{PO}_{4}-\mathrm{P}$ & $\mathrm{SiO}_{3}-\mathrm{Si}$ \\
\hline \multicolumn{12}{|c|}{ Spring cruise } \\
\hline DH01 & 1958.4 & 4.7 & 1953.7 & 1952.9 & 0.04 & 19.65 & 28.26 & 16.53 & 0.745 & - & 22.81 \\
\hline YZ13 & 2318.3 & 0.7 & 2317.6 & 2304.0 & 0.06 & 18.78 & 30.83 & 6.41 & 0.403 & - & 16.67 \\
\hline PN10 & 2854.5 & 0.1 & 2853.3 & 2854.2 & $<0.01$ & 19.36 & 30.82 & 0.30 & 0.042 & - & 16.72 \\
\hline DD15 & 2215.0 & 0.7 & 2214.3 & 2187.5 & $<0.01$ & 19.72 & 31.66 & 0.24 & - & - & 14.98 \\
\hline DH31b & 2555.6 & 14.3 & 2541.2 & 2538.7 & 0.06 & 20.07 & 31.55 & - & - & - & 13.15 \\
\hline DH21a & 2484.4 & 3.2 & 2481.2 & 2480.0 & 0.02 & 19.02 & 31.34 & 3.44 & 0.165 & - & 18.98 \\
\hline \multicolumn{12}{|c|}{ Fall cruise } \\
\hline PN09 & 55220.9 & 55103.2 & 100.9 & 37873.9 & 2.75 & 17.30 & 31.91 & 7.75 & 0.26 & 0.27 & 15.79 \\
\hline PN08 & 67856.4 & 67744.3 & 112.1 & 33451.9 & 2.96 & 18.40 & 33.18 & 7.72 & 0.37 & 0.52 & 13.89 \\
\hline
\end{tabular}

\section{Spring 2011}

Summer 2009

Fall 2010

Winter 2009
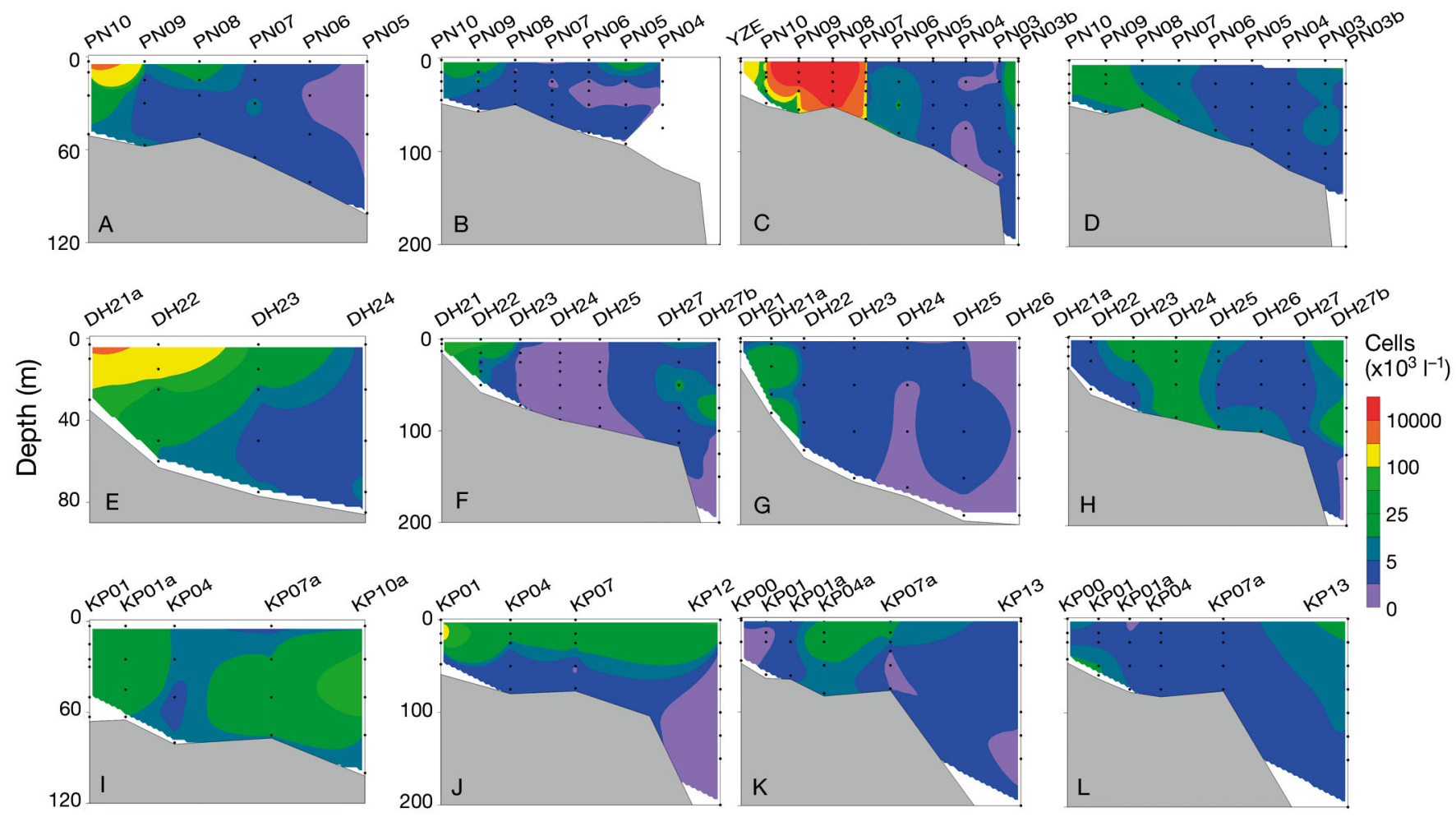

Fig. 7. Distribution of phytoplankton abundance $\left(\times 10^{3}\right.$ cells $\left.\mathrm{l}^{-1}\right)$ in $(\mathrm{A}-\mathrm{D})$ transect $\mathrm{A},(\mathrm{E}-\mathrm{H})$ transect $\mathrm{B}$, and $(\mathrm{I}-\mathrm{L})$ transect $\mathrm{C}$ (see Fig. 1) during 4 cruises (spring, summer, fall, and winter) in the East China Sea. Station numbers are marked along the top $x$-axes

\section{Transect distribution of phytoplankton}

The distribution of phytoplankton abundance along transects $\mathrm{A}, \mathrm{B}$, and $\mathrm{C}$ in 4 seasons is shown in Fig. 7. The cell abundance in transect A was higher in coastal water than in offshore water, and was mainly concentrated in the upper layer in spring and summer (Fig. 7A,B). In fall and winter, cells were distributed homogeneously throughout the water column in the coastal water (Fig. 7C,D). Along transect $B$, high abundances mainly appeared in the inshore water, except in winter when high abundance was recorded at Stns DH23 and DH24 (Fig. 7H). Both in summer and winter, patches of high abundance appeared at the offshore Stns DH27 and DH27b, with the dominant species being Thalassionema frauenfeldii and T. nitzschioides (Fig. 7F,H). Along transect $\mathrm{C}$, high abundances appeared in coastal water, with 
dominant species being chain-forming diatoms such as $P$. delicatissima and T. nitzschioides in spring and summer (Fig. 7I,J). In the offshore water, a relatively high abundance of chain-forming diatoms was observed in the subsurface water of Stn KP10a in spring (Fig. 7I).

\section{Vertical distribution of phytoplankton}

Three typical regions in the ECS were recognized based on a temperature-salinity diagram (Fig. 3): coastal water, shelf mixed water, and KW. Vertical distributions of phytoplankton abundance in the 3 water systems are shown in Fig. 8A-L. Phytoplankton abundance showed different distribution patterns vertically in the 3 water systems. In the coastal water, phytoplankton abundance decreased gradually from the surface layer to the bottom in spring and summer (Fig. 8A,B), while no such trend was observed in fall or winter (Fig. 8C,D). In the shelf mixed water, distribution of phytoplankton abundance showed a similar trend in spring and summer, both reaching the maximum between depths of 25 and $35 \mathrm{~m}$ (Fig. 8E,F). In fall and winter, no obvious distribution pattern was observed (Fig. 8G,H). In the offshore KW, the phytoplankton abundance peaked at $50 \mathrm{~m}$ in spring and summer, and at $25 \mathrm{~m}$ in fall (Fig. 8I-K) and was distributed homogeneously in the water column in winter (Fig. 8L).

\section{Correlations and CCA}

Significant negative correlations were observed between phytoplankton abundance and temperature and salinity in the surface layer both in spring and summer $(\mathrm{p}<0.05)$, and no significant correlation was observed between phytoplankton abundance and temperature and salinity in fall and winter (Table 5). Significant negative correlations were observed between phytoplankton abundance and salinity in summer and fall $(\mathrm{p}<0.05)$ in all water layers, and no significant correlation was observed in spring and winter. For nutrients, phytoplankton abundances correlated positively with phosphate and silicate concentration in the surface layer in spring ( $p<0.05)$, while no obvious correlation was observed between phytoplankton abundances and any nutrient concentration in the surface layer in summer, fall, or winter. For the overall samples, phytoplankton abundances correlated positively with phosphate concentration in spring, summer, and fall ( $p<0.05)$, and correlated positively with silicate concentration in fall and winter $(\mathrm{p}<0.01)$. In fall, phytoplankton abundance correlated positively with nitrate concentration $(\mathrm{p}<0.01)$.

CCA biplots of dominant species and environmental parameters are presented in Fig. 9. In the spring biplot, the upper left section represents the coastal water with high nutrient concentrations and stability, and the lower right section represents the offshore water with low nutrient concentrations and high temperature and salinity (Fig. 9A). P. dentatum abundance showed a close positive correlation with stratification index and nitrate concentration. Trichodesmium thiebaultii and Guinardia stolterforthii abundances showed a positive correlation with temperature. There was no correlation between $P$. sulcata abundance and any environmental parameter (Fig. 9A). In the summer biplot, the upper part represents the coastal water with high nutrient concentrations and the lower left represents the offshore water with high temperature and salinity (Fig. 9B). Similar to spring, dinoflagellate abundances showed a clear positive correlation with stratification index. Most of the diatom species showed a close positive correlation with phosphate concentration. T. thiebaultii abundance showed a close correlation with temperature and salinity (Fig. 9B). In fall, the abundances of most dominant diatom species were positively correlated with silicate concentration, except that $P$. sulcata abundance did not show a close correlation with any environmental parameter (Fig. 9C). In the winter biplot, the lower left section represents the nutrientenriched coastal water and the right half represents the offshore water with high temperature and salinity (Fig. 9D). P. sulcata, Entomoneis alata, and Pleurosigma affine abundances showed positive correlations with phosphate, nitrate, and silicate concentrations, while other species showed good correlations with nitrite and salinity (Fig. 9D).

\section{DISCUSSION}

\section{Turbulence and community composition}

The phytoplankton community in the ECS was mainly composed of diatoms and dinoflagellates (Table 1), with diatoms dominating throughout the year and dinoflagellates only dominating in spring and summer (Table 2). Dinoflagellates showed lower frequency in fall and winter than in spring and summer (Table 3). Seasonal variation in the phytoplankton community was always correlated with the 

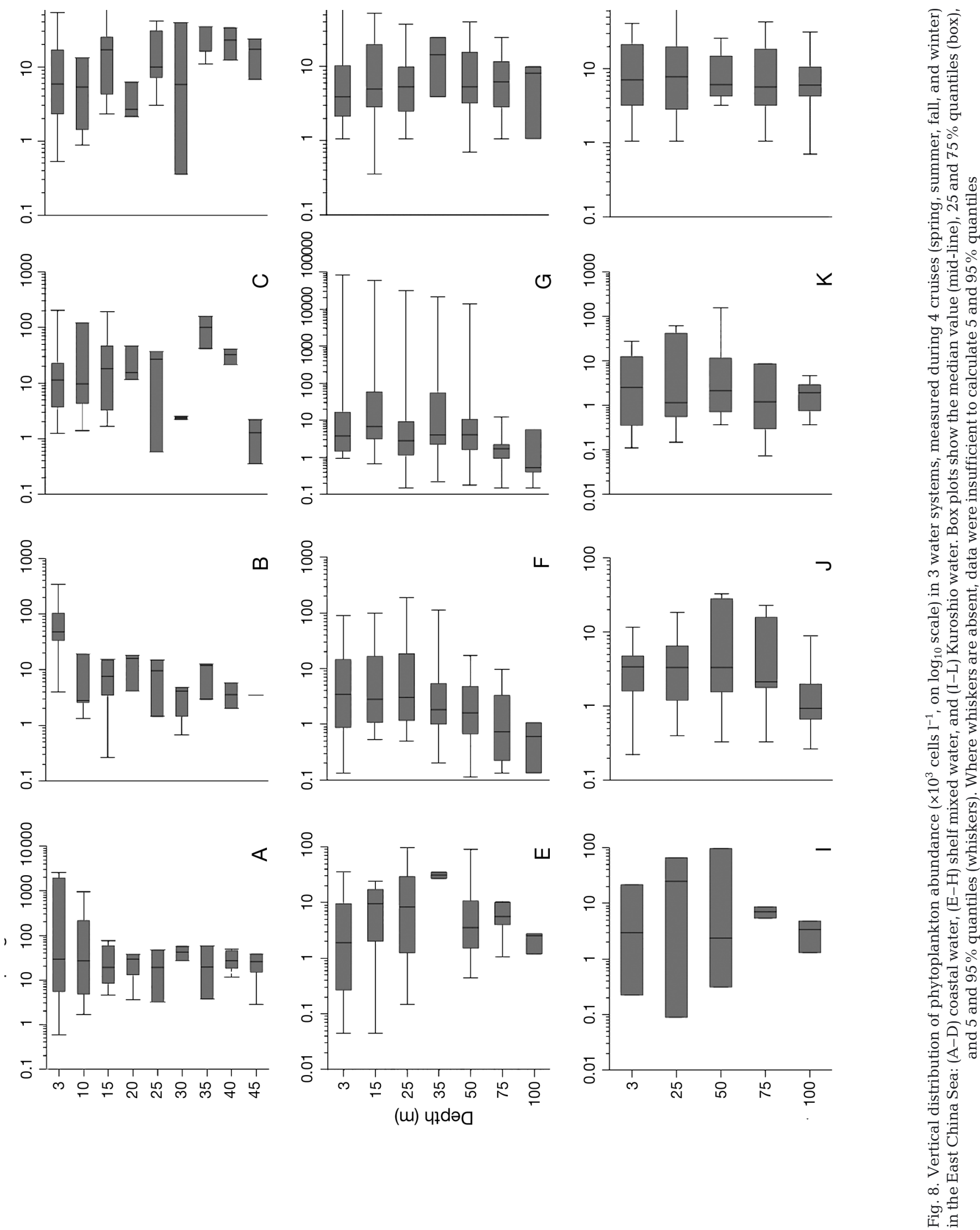
Table 5. Correlation analysis (R values) between phytoplankton abundances and environmental parameters during 4 cruises (spring, summer, fall, and winter) in the East China Sea. T: temperature, S: salinity, I: Stratification index. ${ }^{*} \mathrm{p}<0.05$, ${ }^{* *} \mathrm{p}<0.01$, na: not analyzed

\begin{tabular}{|llllclccc|}
\hline \multirow{2}{*}{ Season } & Samples & $\mathrm{T}$ & $\mathrm{S}$ & $I$ & Nitrate & Nitrite & Phosphate & Silicate \\
\hline \multirow{2}{*}{ Spring } & Surface & $-0.23^{*}$ & $-0.53^{* *}$ & $0.48^{* *}$ & -0.07 & -0.14 & $0.44^{*}$ & $70.54^{* *}$ \\
& All & -0.07 & 0.04 & na & 0.12 & -0.07 & $0.13^{*}$ & 0.17 \\
\multirow{4}{*}{ Full } & Surface & $-0.33^{*}$ & $-0.35^{*}$ & $0.39^{*}$ & 0.16 & -0.01 & -0.08 & 0.13 \\
\multirow{4}{*}{ Winter } & All & 0.28 & $-0.329^{* *}$ & na & 0.001 & 0.018 & $-0.26^{* *}$ & -0.06 \\
\multirow{4}{*}{ All } & Surface & -0.23 & -0.15 & -0.03 & 0.01 & -0.13 & -0.07 & 0.03 \\
& All & -0.17 & $-0.30^{* *}$ & na & $0.23^{* *}$ & -0.07 & $0.13^{*}$ & $0.36^{* *}$ \\
& Surface & -0.11 & -0.02 & -0.06 & 0.14 & -0.10 & 0.22 & 0.12 \\
& All & -0.22 & -0.12 & na & 0.08 & -0.06 & 0.25 & $0.24^{* *}$ \\
& Surface & -0.09 & -0.06 & -0.04 & 0.01 & -0.04 & -0.03 & 0.09 \\
& All & 0.08 & $-0.27^{* *}$ & na & -0.03 & -0.01 & 0.07 & $0.10^{* *}$ \\
\hline
\end{tabular}

fluctuation of physico-chemical environmental parameters. The average wind speed above the sea in the ECS was $>8 \mathrm{~m} \mathrm{~s}^{-1}$ in fall and winter, and $<2 \mathrm{~m} \mathrm{~s}^{-1}$ in spring and summer $(\mathrm{J} . \mathrm{Hu}$, Xiamen University, unpubl. data). The ECS was stratified in spring and summer (Fig. 4A,B). In fall and winter, however, the water column was homogeneously mixed under the influence of the strong monsoon, except the stratified inshore water under the influence of YDW in fall (Fig. 4C,D). Numerous studies have revealed that water turbulence level has a direct effect on the composition of phytoplankton community. Margalef (1978) proposed the classical 'Margalef mandala' that dinoflagellates are not favored in highly turbulent water conditions and a dinoflagellate to diatom community shift would occur when water turbulence levels increased. Because they possess flagellae, dinoflagellates are motile and can regulate their position in the water column. In stratified waters, the motility of dinoflagellates favors their growth by overriding sinking and contributing to the acquisition of nutrients from deep waters (Estrada \& Berdalet 1997). In contrast, being non-motile and with fast potential growth rates, diatoms can thrive in turbulent and nutrient-rich waters, and the disadvantage of non-motility can be compensated by resuspension of cells due to turbulence. Moreover, diatoms and dinoflagellates respond differently to turbulence. Although turbulence has been reported to supply nutrients for phytoplankton (Estrada \& Berdalet 1997), there is growing evidence that turbulence directly influences dinoflagellate physiology (Thomas et al. 1995, Juhl et al. 2000, Juhl \& Latz 2002). Many in situ and mesocosm experiments have revealed that dinoflagellates are more susceptible to water turbulence, and their growth is inhibited when turbulence increases (Thomas \& Gibson 1990). The effects of water turbulence on dinoflagellates mainly include inhibition of cell division, morphological damage, and disruption of nutrient-retrieval migrations (Smayda 1997). In Lake Kinneret, Israel, the division rate of Peridinium gatunense was inhibited when wind speed exceeded $3.5 \mathrm{~m} \mathrm{~s}^{-1}$ (Pollingher \& Zemel 1981). According to Estrada \& Berdalet (1997), negative effects of turbulence on dinoflagellate growth appeared at turbulent kinetic energy dissipation rates exceeding $0.1 \mathrm{~cm}^{2} \mathrm{~s}^{-3}$, which are found typically in shallow estuarine or coastal areas subjected to intense winds. Sullivan et al. (2003) studied vertical distributions of Alexandrium catenella populations in relation to hydrographic flow fields in the summer in East Sound, Washington, USA, and found that $A$. catenella actively concentrated at depths with low turbulence levels. These observations lead us to speculate that direct effects of turbulence on dinoflagellate populations in the shallow continental shelf of the ECS are important. In contrast, diatoms can live through the strong turbulence due to protection from their silicified cell walls, which is a distinct survival advantage over fragile dinoflagellates in turbulent environments (Hamm et al. 2003). Our CCA analysis also revealed that several dominant dinoflagellate species correlated positively with the water stratification index in spring and summer (Fig. 9), indicating that highly stabilized water favors the growth of these dinoflagellates. Therefore, water turbulence may influence seasonal variation in the phytoplankton community in the ECS.

A simple scenario for seasonal succession patterns of the phytoplankton community on the continental shelf of the ECS based upon water turbulence is proposed here (Fig. 10). In spring, although the stratified water associated with the high temperature prevents the up-transportation of nutrients from the bottom 

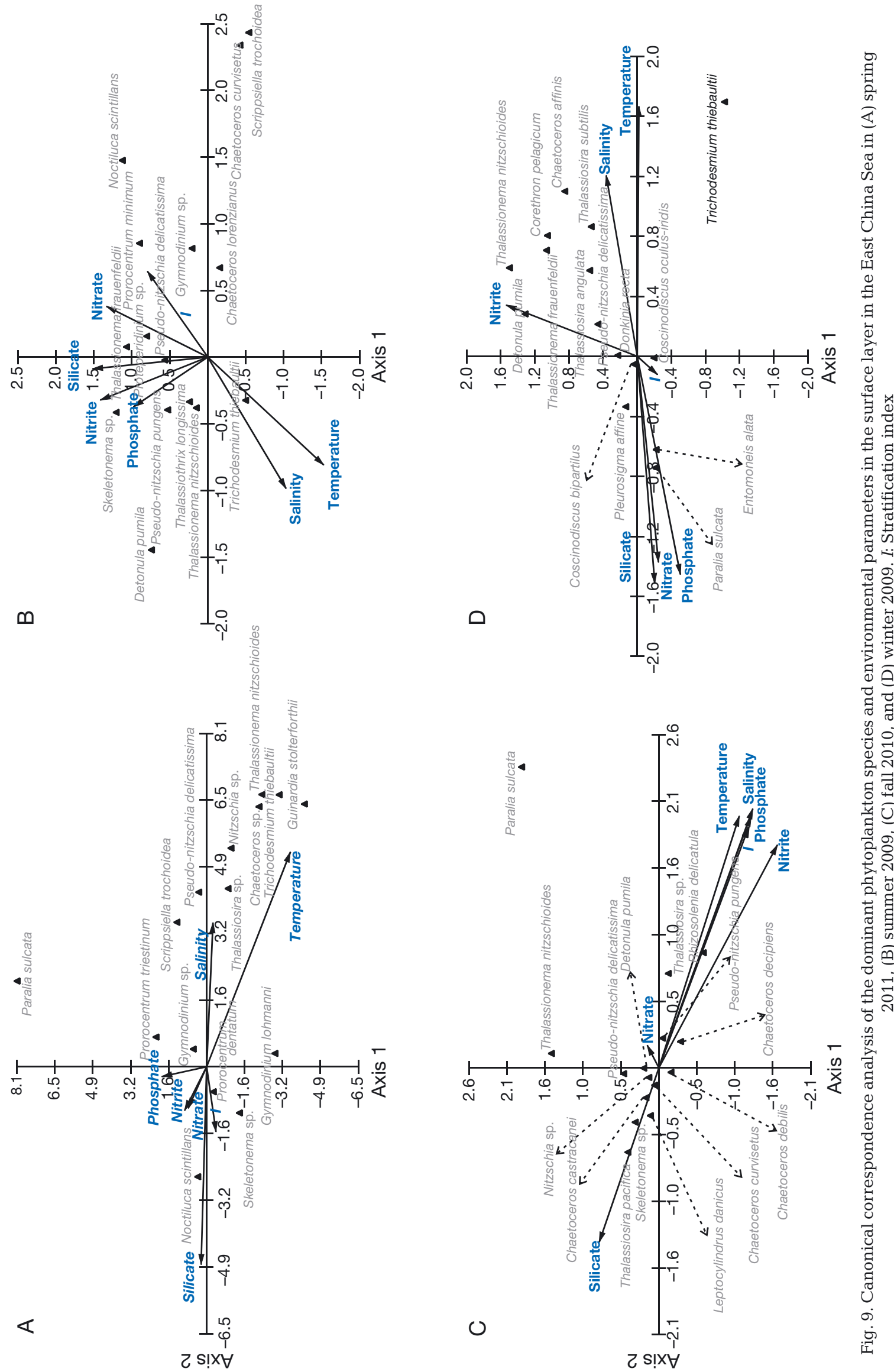
layer, the increased Yangtze River discharge can bring significant amounts of nutrients into the continental shelf of the ECS (Gong et al. 2003). Regeneration of nutrients in the water column is another important nutrient source for phytoplankton growth in the coastal area (Li et al. 2009). Most of the stations near the Yangtze River estuary and the Zhejiang coastal area were characterized by high nitrate concentration $\left(>15.0 \mu \mathrm{mol} \mathrm{l}^{-1}\right)$ in the spring cruise. Due to the stable water and sufficient nutrients, the Yangtze River estuary and adjacent water bloomed frequently, and the dinoflagellate Prorocentrum dentatum has been reported to be the most common redtide species in spring since 2000 (Tang et al. 2006). Other red-tide species also bloomed intermittently, including Skeletonema costatum and Karenia mikimotoi, which bloomed successively in most cases (Tang et al. 2006). In summer, the surface nutrient concentrations were also high in coastal water (Fig. 2J) due to runoff from the Yangtze River (Fig. 2F). Similar to spring, the dominant species were diatoms and dinoflagellates (Table 2). High nutrient levels and stable water resulted in high chl $a$ values in coastal water in summer (Fig. 2N), and Skeletonema sp. and Noctiluca scintillans are the most common bloom-causing species (Tang et al. 2006). However, no bloom was observed during the summer cruise, with Thalassionema nitzschioides,

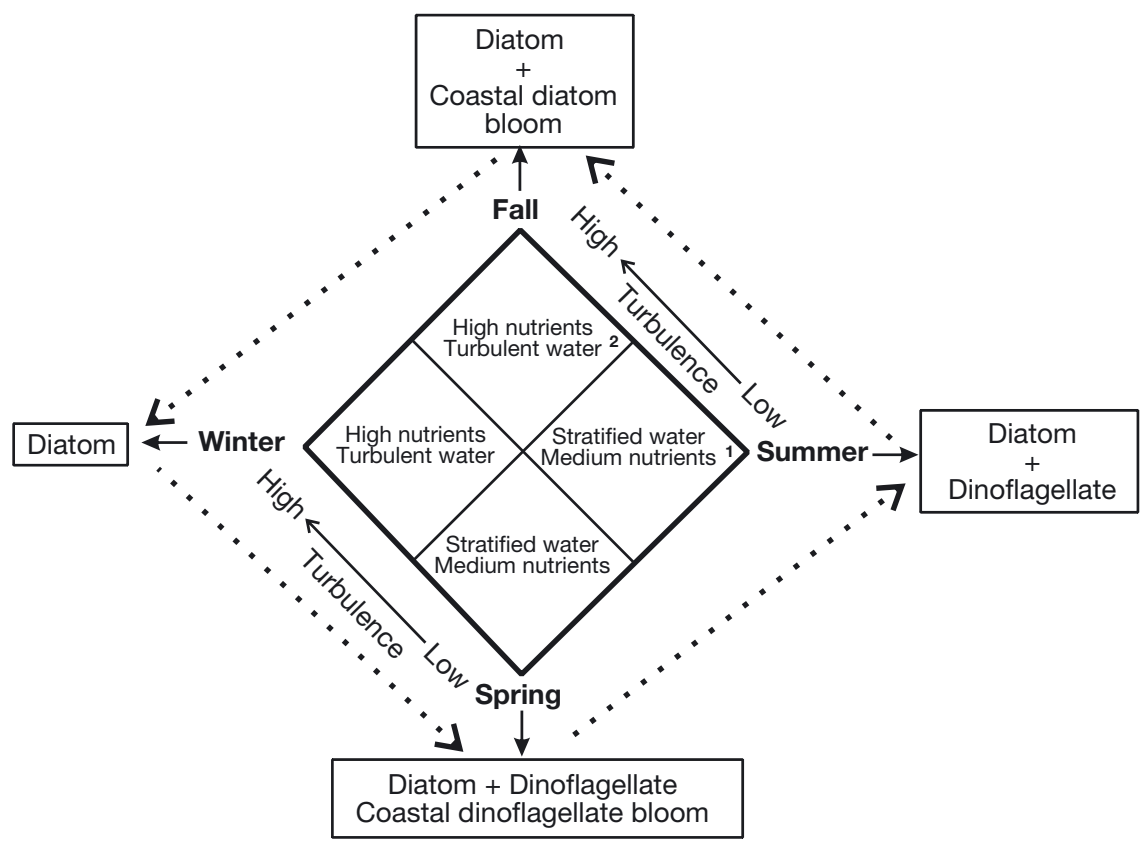

Fig. 10. Schematic of seasonal succession of the phytoplankton community in the East China Sea. $\left({ }^{1}\right)$ When Yangtze River Diluted Water (YDW) inputs sufficient nutrients, the coastal waters facilitate algal blooms. $\left({ }^{2}\right)$ Inshore water was stratified under the influence of YDW
Pseudo-nitzschia pungens, Skeletonema sp., and $S$. trochoidea co-dominating the phytoplankton community. In fall, stratified water appeared in the Yangtze River estuary due to the low-density YDW (Fig. 4C), and the nitrate concentrations were relatively high in the coastal water $\left(>25.0 \mu \mathrm{mol} \mathrm{l}^{-1}\right)$. The stratified water and high nutrient levels favored the fall diatom bloom forming in the Yangtze River estuary. In the offshore water, however, strong mixed water with high turbulence level restrained the growth of dinoflagellates. In winter, the discharge of YDW decreased as indicated by the isohaline of salinity 31 (Fig. 2H), but the nutrient concentrations increased because of strong water mixing (Fig. 2L). The water column on the whole continental shelf (both inshore and offshore) was vertically mixed as a result of surface cooling and a strong northeastern monsoon (Chen et al. 1994), and phytoplankton biomass significantly decreased due to the low temperature, irradiance, and high water turbulence (Gong et al. 2003).

\section{Comparison between spring and fall blooms}

The Yangtze River estuary and adjacent water are affected by anthropogenic inputs, and diatoms and dinoflagellates are the most common algal bloom species in this area (Tang et al. 2006). $P$. dentatum was reported to be the most frequent bloom-causing species, followed by $S$. costatum, K. mikimotoi, and Chaetoceros curvisetus (Shen et al. 2011). As diatoms and dinoflagellates show great differences in cell morphology, structure, and nutrition mode, they differ greatly in their bloom strategy. In spring, the P. dentatum contributed over $97 \%$ of total phytoplankton abundance at the bloom stations. In fall, however, several diatom species such as Pseudonitzschia delicatissima, Leptocylindrus danicus, and Rhizosolenia delicatula showed high cell abundances $\left(>10^{6}\right.$ cells $\mathrm{l}^{-1}$ ) in addition to Chaetoceros debilis, and community diversity was relatively high at the bloom stations (Table 4). Many studies have revealed that dinoflagellate blooms present lower diversity than diatom blooms, and the allelopathic effect, a survival strategy for dinoflagellates competing 
for nutrients with other phytoplankton species, was suggested to play a significant role regulating phytoplankton communities in blooms (Smayda \& Reynolds 2003). The allelopathic substances are mainly used to inhibit the growth of other phytoplankton species (Smayda 1997). Although no reports to date have shown an allelopathic effect of $P$. dentatum, other Prorocentrum species such as $P$. minimum have been reported to show this ability (Heil et al. 2005). Thus in the spring bloom, the fairly low cell abundance of other species might be caused by such an allelopathic effect of $P$. dentatum. Different from dinoflagellates blooms, few diatom species are reported to produce allelopathic substances (Bates 2000), and diatom blooms are always characterized by high species diversity, suggesting that the assembled diatom species have relatively lower competition coefficients (Smayda \& Reynolds 2003).

Another difference between these 2 blooms was the column distribution of cells. At the $6 P$. dentatum bloom stations, the cells mainly concentrated in the upper $10 \mathrm{~m}$ of water, and decreased rapidly with increased depth (Fig. 7A). However, in the fall C. debilis bloom, the whole water column was characterized by high cell abundance (Fig. 7C). Due to the fast turnover rates, phytoplankton cells in the upper layer usually die and sink quickly, and eventually sink into the bottom water. However, the cell abundance was relatively low in the water layers deeper than $10 \mathrm{~m}$ in the spring $P$. dentatum bloom, raising the question of where the cells went. Since meso- and micro-zooplankton grazing is not the main controlling factor in the stationary or decline period of spring blooms in the Yangtze River estuary (Sun et al. 2007, Sun \& Song 2009), the dead cells were most likely decomposed in the water column before reaching the bottom. Heiskanen \& Kononen (1994) found that in a dinoflagellate Peridiniella catenata bloom, the cells disintegrated in the water column before reaching the bottom water. In the northern Baltic Sea, similar scenarios have also been found, i.e. directly sedimenting vegetative Peridinium hangoei bloom cells accounted for only a small fraction of the population, while large amounts of $P$. hangoei phytodetritus were observed in the bottom water (Heiskanen 1993). In contrast, the diatoms may decompose more slowly due to their rigid silicified cell wall (Fry et al. 1996). Moreover, in diatomdominated blooms, phytoplankton cells are usually subjected to rapid sedimentation out of the water column due to fast sinking rates, which leaves less time for zooplankton and bacteria to decompose them (Passow 1991). The sinking rates of phytoplankton cells at the $P$. dentatum bloom stations in spring were also obviously lower than those measured at the Skeletonema sp. bloom stations in summer in the Yangtze River estuary (S. Guo unpubl. data, measured with the SETCOL method of Bienfang 1981). In the highly productive Yangtze River estuary and adjacent water, the fate of phytoplankton organic matter is largely determined by the dominant phytoplankton groups. With fast sinking rates, diatom-dominated blooms are subjected to rapid sedimentation. Dinoflagellates, however, may be disintegrated quickly in the water column and contribute less to the sinking phytodetrital pool with a large part being recycled in the water column. These differences can have a significant effect on the export of produced organic material during the bloom period in the ECS.

\section{Cell abundance in different water systems}

The water circulation in the ECS is complex and varies both spatially and temporally (Yanagi \& Takahashi 1993), and several physico-chemical parameters, including light availability and nutrient concentration, co-vary with the seasonal variation in water circulation (Gong et al. 2003). In this study, the availability of nutrients and light differed among water types, and the coastal water was always nutrientenriched while offshore water was light-sufficient (Table 6). For example, under the influence of YDW and a strong northeastern monsoon in winter, coastal water has high nutrient concentrations but low PAR, while offshore water has low nutrient concentrations and high PAR (Table 6). Although summer PAR data were not available in this study, according to Gong et al. (2003), coastal water is characterized by higher attenuation of PAR and nutrient enrichment, and offshore water has relatively high PAR availability and low nutrient concentrations in summer. The seasonal variation in environmental parameters mentioned above should greatly influence the phytoplankton community. More details should be considered based on different water types when studying phytoplankton in the ECS. Clear seasonal variation in phytoplankton abundance was found in coastal water and shelf mixed water (Table 6). In the coastal water, mean phytoplankton abundance was highest in

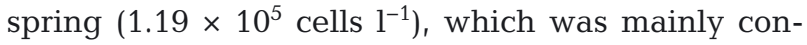
tributed by dinoflagellates. In summer and fall, phytoplankton abundance was lower than in spring and was dominated by diatoms. In winter, the mean 


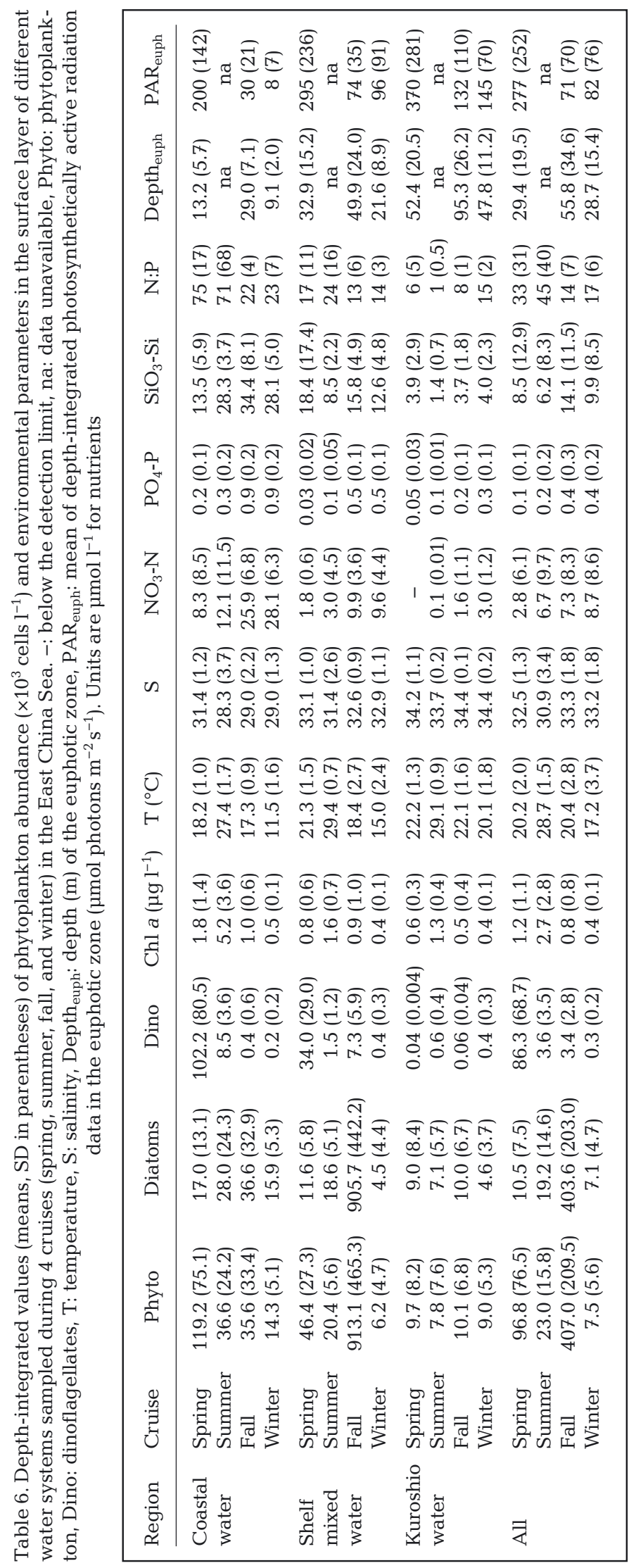

of depth-integrated abundances was quite low $\left(1.43 \times 10^{4}\right.$ cells $\left.\mathrm{l}^{-1}\right)$. In the shelf mixed water, phytoplankton abundance was higher in spring and fall than in summer and winter due to the spring $P$. dentatum bloom and fall $C$. debilis bloom in the Yangtze River estuary and adjacent water. In the offshore KW, phytoplankton abundances were similar among the 4 seasons and were mainly composed of diatoms. In the whole ECS, the cell abundance was highest in fall, followed by spring and summer, and lowest in winter. Phytoplankton abundances in coastal water and shelf mixed water fluctuated more among seasons than in offshore KW. It should be noted that seasonal variation in chl a data in different water types did not match phytoplankton abundances. In all 3 water types, chl a concentration was highest in summer, followed by spring and fall, and lowest in winter (Table 6). This was likely caused by the difference in phytoplankton community composition among seasons. In spring and fall, although phytoplankton abundances were high at the bloom stations, the small size of dominant cells constrained the total biomass. As $P$. dentatum and $C$. debilis are both smallsized species, the cellular biomasses of these species are quite low. In summer, dominant species including T. nitzschioides, $P$. pungens, $T$. frauenfeldii, and Gymnodinium simplex were all large-celled species, with cellular biomass ratios higher than both $P$. dentatum and $C$. debilis, thus the relatively lower cell abundance in summer may still express higher chl a values. According to Furuya et al. (2003), cyanobacteria and prochlorophytes accounted for 24 to $63 \%$ of the total chl $a$ at the surface layer both inshore and offshore in the ECS in summer, and the biomass of prochlorophytes, chrysophytes, and prymnesiophytes increased with depth and became important around the subsurface chl a maximum layer. The dominance of pico- and nano-sized phytoplankton cells in summer might also contribute to the high chl a values, but in the present study cells $<5 \mu \mathrm{m}$ were not considered.

In recent years, both nitrogen and phosphorus inputs have increased in the Yangtze River estuary, with nitrogen increasing more, due to indiscriminate use of nitrogen fertilizers in the farmland along the Yangtze River (Li et al. 2007). As a result, the coastal water of the ECS is characterized by high nitrogen concentration and relatively low phosphorus concentration, which is similar to many other estuaries and coastal waters around the world (Turner et al. 1990, Rudek et al. 1991, Yin et al. 2004). Phosphorus limitation has also been reported in previous studies in the Yangtze River estuary and 
adjacent waters (Harrison et al. 1990, Li et al. 2009), similar to many coastal waters influenced by river inputs, including the Chesapeake Bay (Fisher et al. 1992), North Sea (Riegman et al. 1990), and northern Baltic Sea (Lignell et al. 1992). In spring and summer, the coastal water was relatively high in nitrate concentration, whereas phosphate was not sufficient, according to the Redfield ratio of 16:1 $(\mathrm{N}: \mathrm{P})$. Several stations in spring and summer had phosphate concentrations below the detection limit in the surface layer (data not shown), indicating phosphorus-limitation in the coastal water in these 2 seasons. In fall, the nutrient concentrations were high (Fig. 2K) and coastal water was stratified (Fig. 4C), which favored the formation of diatom blooms. In winter, the nutrient concentrations in the coastal water were relatively high due to strong mixing under the influence of the northeastern monsoon, and low temperature and PAR are likely responsible for the low phytoplankton abundance (Table 6). In the shelf mixed water, nutrients accumulated beneath the euphotic zone in spring and summer (Fig. 4I,J), and the nitrate and phosphate concentrations in the surface layer were quite low $\left(<2 \mu \mathrm{mol} \mathrm{l^{-1 }}\right)$. Silicate concentrations were relatively high $\left(>8 \mu \mathrm{mol} \mathrm{l}^{-1}\right)$ at most stations in this area and should not limit phytoplankton growth in the surface water. The nitrate and phosphate concentrations are key limiting factors for phytoplankton growth in spring and summer in the shelf mixed water. In fall and winter, an intermediate amount of nutrients was found in the shelf mixed water (Table 6), due to the water mixing caused by the prevailing northeastern monsoon. Similar to coastal water in winter, temperature and irradiance illumination might determine the seasonal variation of phytoplankton biomass in the shelf mixed water in fall and winter, as nutrient concentrations were relatively high in this area (Table 6). In the offshore KW, the supply of subsurface nutrients to the euphotic zone went through the strong stratification layer (Fig. 4K,L), and the nutrient concentrations in the surface layer were quite low throughout the year (Table 6). Both nitrogen and phosphorus could limit phytoplankton growth in this area.

\section{Dominant species and their preferred environmental conditions}

Suitable environmental conditions vary greatly among different phytoplankton groups and even different species. A good correlation was observed be- tween $P$. dentatum abundance and nitrate plus nitrite concentrations and low salinity values in spring (Fig. 9A). Wang \& Huang (2003) found that the most suitable temperature and salinity range for $P$. dentatum is from 18 to $22^{\circ} \mathrm{C}$ and 21 to 31 , respectively, and this species showed strong competitive ability with other phytoplankton species under low phosphate concentration. During the spring cruise, a decrease in salinity and an increase in nutrient concentrations with high N:P ratio due to the runoff of Yangtze River could be determining factors in triggering $P$. dentatum blooms in coastal water. In spring, summer, and fall, Skeletonema sp. showed a positive correlation with nutrient levels and a negative correlation with temperature and salinity (Fig. 9A-C). S. costatum is a well known algal bloom-causing species in the Yangtze River estuary (Tang et al. 2006). Compared to $P$. dentatum, the optimum temperature range of $S$. costatum is wider, from 15 to $25^{\circ} \mathrm{C}$. Semi-continuous dilution experiments revealed that $S$. costatum is more competitive in nutrient-rich environments, while $P$. dentatum is more competitive in nutrientpoor environments (Wang et al. 2006), indicating that $S$. costatum is more dependent on high nutrient concentration. T. thiebaultii showed obvious positive correlations with temperature and salinity in spring, summer, and winter (Fig. 9A,B,D). It is an oceanic species and is abundant in summer throughout the Kuroshio Current water (Chang et al. 2000). However, previous studies have indicated that this species can bloom in the Yangtze River estuary (Ding et al. 2009), indicating that it has a wider range of optimum environmental conditions for growth than previously expected. P. sulcata is a frequently dominant species in the ECS throughout the year (Table 3). In winter, it can be the most dominant species on the continental shelf of the ECS (Furuya et al. 1996). However, this species showed no obvious correlation with any environmental parameter in spring and fall (Fig. 9A,C). Studies revealed that this species is commonly found in the benthos of coastal environments in summer and turbulent upper waters in winter (Cahoon \& Laws 1993, McQuoid \& Nordberg 2003), with a low affinity for light (Hobson \& McQuoid 1997). Surface water properties and water column stability are important for the abundance of $P$. sulcata along the coast, and up-transport of $P$. sulcata cells to upper water from the bottom in turbulent water is important for its dominance in winter (Furuya et al. 1996). In our winter cruise, however, this species was concentrated in the northern part of the ECS (Fig. 5D), which requires further study in this area. 
Some other chain-forming diatoms were the main dominant species in the ECS throughout the year (Table 2). In spring, they correlated positively with temperature and salinity, and negatively with nutrient concentrations, whereas in summer, they were positively correlated with nutrient concentrations. Most of the chain-forming diatoms correlated with silicate concentration in fall and did not show close correlations with any environmental parameter in winter (Fig. 9). Phytoplankton communities change in dominant species composition in response to the variation in environmental conditions among seasons. In some cases, a phytoplankton species is characterized by an environmental parameter in one system, while in another aquatic system it might behave differently, thus leading to different optima and tolerances (Resende et al. 2005). Chain-forming diatoms form the background assemblage in the continental shelf of the ECS, and will change into the dominant group when environmental conditions are favorable for their growth (Chiang et al. 1999, 2004).

\section{$\mathrm{N}: \mathrm{P}$ and $\mathrm{Si}: \mathrm{N}$ ratios}

Studies of the factors regulating phytoplankton communities have been carried out for several decades, but the role of nutrient limitation and the resource-ratio hypothesis in influencing the phytoplankton community is still not fully understood. The Yangtze River estuary and adjacent water, influenced greatly by YDW, was characterized by high N:P ratios in all 4 seasons, especially in spring and summer (Wong et al. 1998). The average values of N:P in the coastal water were generally $>20$ in all 4 seasons in our study (Table 6). However, in the offshore shelf mixed water and $\mathrm{KW}, \mathrm{N}: \mathrm{P}$ ratios were generally around or lower than 16:1 in the 4 seasons (Table 6), which was quite different from the coastal water, and thus there might be a shift in the limiting factor(s) for primary production from the inshore water influenced by the YDW to the offshore water. Diatoms can easily become dominant when growing in non-limiting conditions (Smayda 1997), whereas when nutrients are limited, diatoms are more easily affected than dinoflagellates, especially under phosphorus limitation (Egge 1998). Our analysis revealed a relatively good correlation between the relative abundance of diatoms and dinoflagellates with N:P ratios in the survey area (Fig. 11). In the surface layer, the relative cell abundance of diatoms was generally higher than $60 \%$ when the N:P ratio was lower than 25 (Fig. 11A). With N:P increasing, the relative cell abundance of diatoms decreased correspondingly $\left(\mathrm{R}^{2}\right.$ $=0.578$ ). The relative abundance of dinoflagellates showed the opposite relationship $\left(\mathrm{R}^{2}=0.592\right)$. This was most remarkable at the bloom stations in spring, when the phosphate concentration in the surface layer was under the detection limit and the cell abundance of $P$. dentatum exceeded $10^{6}$ cells $1^{-1}$ (Table 4). Yin et al. (2000) reported a similar phenomenon in the Pearl River estuary, where phosphorus limitation favored the dominance of dinoflagellates. The halfsaturation coefficient of phytoplankton species for nutrients, $K_{s}$, is generally used as an indicator of the affinity for nutrients, and the higher the $K_{s}$, the lower the affinity (Smayda 1997). We found no references for the $K_{S}$ of $P$. dentatum for phosphate in the literature, but a $K_{S}$ of $1.96 \mu \mathrm{mol} \mathrm{l^{-1 }}$ has been reported for $P$. minimum (Smayda 1997). In spring, the average DIP concentration in the surface layer was $0.3 \pm 0.14 \mu \mathrm{mol}$ $1^{-1}$ (mean $\pm \mathrm{SD}$ ) in the coastal area, much lower than the $K_{s}$ of Prorocentrum species. In order to adapt to low phosphate concentrations, dinoflagellates such as $P$. dentatum may utilize dissolved organic phosphate (DOP) to survive (Smayda 1997). Huang et al. (2005) found that $P$. dentatum can utilize DOP as the sole phosphorus source via alkaline phosphatase for growth. Huang et al. (2007) also observed that the mean value of DOP accounted for $46.3 \pm 24.7 \%$ (mean $\pm \mathrm{SD}$ ) of the total dissolved phosphorus in spring of 2005 in the ECS, which was a potentially significant phosphorus source for dinoflagellate growth. Thus dinoflagellates may possess a survival advantage over diatoms by utilizing DOP in the ECS. In addition, several previous studies have shown that dinoflagellates have the ability of mixotrophy, and the mixotrophic modes of dinoflagellates include direct engulfment of prey, peduncle feeding, and pallium feeding (Smayda 1997). Stoecker (1999) found that phosphorus limitation was a common factor stimulating dinoflagellates to ingest particulate nutrients in field experiments, which may be another reason for the dominance of dinoflagellates in phosphorus-limited conditions.

Egge (1998) considered that when silicate concentration in the environment was $>2 \mu \mathrm{mol} \mathrm{l}^{-1}$, diatoms could dominate the phytoplankton community if other nutrients were sufficient. In the 4 cruises, the average silicate concentrations were obviously higher than this value both in the inshore and offshore water, and silicate was relatively sufficient and could not be the limiting factor in the Yangtze River estuary and adjacent water. Relative cell abundance versus Si:P ratios also showed no obvious relationship (Fig. 11C,D). Although some studies have suggested 

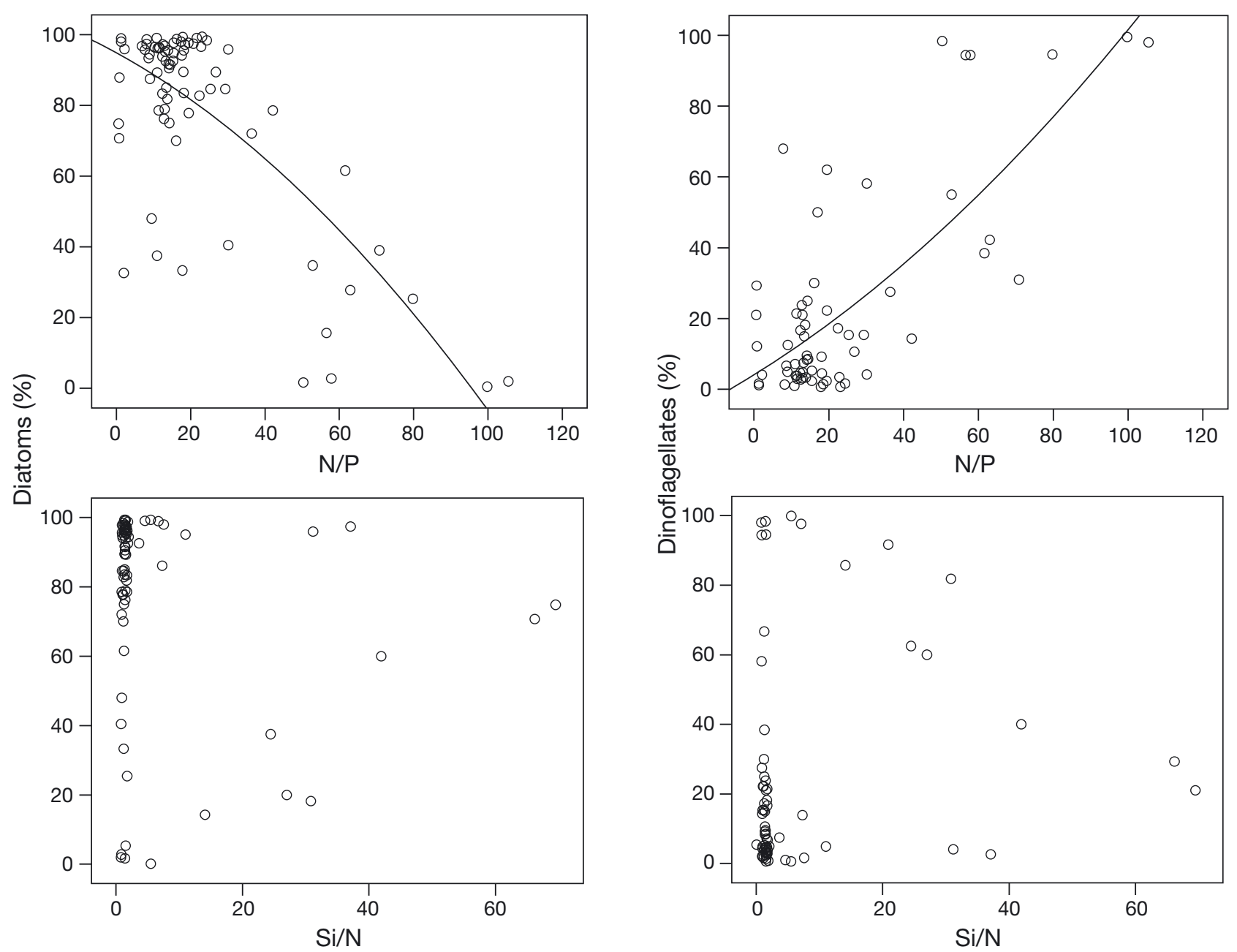

Fig. 11. Relative abundances of diatoms and dinoflagellates versus N:P and Si:N ratios in the surface layer in the East China Sea in all 4 seasons. Stations with nutrient concentrations below the detection limit were omitted

that with the construction of large dams and reservoirs in the Yangtze River basin, significant amounts of silicon should be fixed by phytoplankton before entering the ECS, and dissolved silicate flux into the ECS has decreased sharply in recent years (Li et al. 2007), the effect of silicate limitation on the phytoplankton community was not significant in our study, consistent with a previous study by Wang et al. (2003). Silicon limitation thus warrants further studies in this area.

In summary, our study provides evidence that the distribution pattern of the phytoplankton community in the ECS differed significantly in these 3 water systems both spatially and temporally. The N:P ratio, but apparently not $\mathrm{Si}: \mathrm{N}$, is argued to be a significant factor in regulating phytoplankton community structure and spring coastal dinoflagellate bloom formation in the study area. Besides the controlling factors dis- cussed above, grazing can be of great importance in species succession if there is selective grazing on one particular phytoplankton group. The impact of zooplankton grazing on seasonal variation in the phytoplankton community of the ECS was not considered here. According to Furuya et al. (2003), both protozoan and macrozooplankton grazing activity may be active in the shelf water of the ECS, and both microzooplankton and mesozooplankton might play a significant role in regulating the phytoplankton community in the ECS (Sun et al. 2007, Sun \& Song 2009). In the Yangtze River estuary and adjacent waters, Strombidium sp. was the key microzooplankton species on controlling the formation of $P$. dentatum blooms (Sun et al. 2003). Therefore, an effort should be made in future work to investigate the influence of top-down control on phytoplankton species composition in this area. 
Acknowledgements. We thank Shuqun Song, Qingshan Luan, Wei Ma, and Wei Tian for water sampling, and the crew and captain of the RV 'Dongfanghong2' for logistic support during the cruise. We also thank Chuanjun Du and Xiaofan Luo for helpful communications. Professor Jianyu $\mathrm{Hu}$ provided the wind data. Three anonymous reviewers are appreciated for their helpful and constructive comments. This study was supported by the National Basic Research Program of China (no. 2009CB421202), the Ocean Public Welfare Scientific Research Project for China (201105021-03), the Program for New Century Excellent Talents in University (no. NCET-12-1065), and the National Natural Science Foundation of China (nos. 41176136, 41276124, 40776093, and 40676089) to J.S., and National Natural Science Foundation of China (no. 41306118) to Y.F.

\section{LITERATURE CITED}

> Bates SS (2000) Domoic acid producing diatoms: another genus added! J Phycol 36:978-983

> Bienfang PK (1981) SETCOL_A technologically simple and reliable method for measuring phytoplankton sinking rates. Can J Fish Aquat Sci 38:1289-1294

Cahoon LB, Laws RA (1993) Benthic diatoms from the North Carolina continental shelf: inner and mid shelf. J Phycol 29:257-263

Chang J, Chiang KP, Gong GC (2000) Seasonal variation and cross-shelf distribution of the nitrogen-fixing cyanobacterium Trichodesmium in southern East China Sea. Cont Shelf Res 20:479-492

> Chao S (1990) Circulation of the East China Sea, a numerical study. J Oceanogr Soc Jpn 46:273-295

> Chen CA, Wang S (1999) Carbon, alkalinity and nutrient budgets on the East China Sea continental shelf. J Geophys Res 104:20675-20686

> Chen CS, Beardsley RC, Limeburner R, Kim K (1994) Comparison of winter and summer hydrographic observations in the Yellow and East China Seas and adjacent Kuroshio during 1986. Cont Shelf Res 14:909-929

Chiang K, Chen Y, Gong G (1999) Spring distribution of diatom assemblages in the East China Sea. Mar Ecol Prog Ser 186:75-86

Chiang K, Chou Y, Chang J, Gong G (2004) Winter distribution of diatom assemblages in the East China Sea. J Oceanogr 60:1053-1062

> Dai M, Wang L, Guo X, Zhai W, Li Q, He B, Kao S (2008) Nitrification and inorganic nitrogen distribution in a large perturbed river/estuarine system: the Pearl River Estuary, China. Biogeosci Discuss 5:1545-1585

Ding CL, Sun J, Wang M (2009) The Trichodesmium and Netz-phytoplankton community of the spawning ground in the East China Sea and its adjacent waters in spring. Prog Fish Sci 30:50-56

> Edmond J, Spivack A, Grant B, Hu M, Sung C, Zeng Xiushau C (1985) Chemical dynamics of the Changjiang estuary. Cont Shelf Res 4:17-36

Egge J (1998) Are diatoms poor competitors at low phosphate concentrations? J Mar Syst 16:191-198

Estrada M, Berdalet E (1997) Phytoplankton in a turbulent world. Sci Mar 61:125-140

Falkowski PG, Woodhead AD (1992) Primary productivity and biogeochemical cycles in the sea, Vol 43. Plenum Press, New York, NY
Fisher TR, Peele ER, Ammerman JW, Harding LW Jr (1992) Nutrient limitation of phytoplankton in Chesapeake Bay. Mar Ecol Prog Ser 82:51-63

Fry B, Hopkinson CS, Nolin A (1996) Long-term decomposition of DOC from experimental diatom blooms. Limnol Oceanogr 41:1344-1347

> Furuya K, Kurita K, Odate T (1996) Distribution of phytoplankton in the East China Sea in the winter of 1993. J Oceanogr 52:323-333

- Furuya K, Hayashi M, Yabushita Y, Ishikawa A (2003) Phytoplankton dynamics in the East China Sea in spring and summer as revealed by HPLC-derived pigment signatures. Deep-Sea Res II 50:367-387

- Gao X, Song J (2005) Phytoplankton distributions and their relationship with the environment in the Changjiang Estuary, China. Mar Pollut Bull 50:327-335

> Gasol JM, Giorgio PA, Duarte CM (1997) Biomass distribution in marine planktonic communities. Limnol Oceanogr 42:1353-1363

> Gong GC, Lee Chen YL, Liu KK (1996) Chemical hydrography and chlorophyll a distribution in the East China Sea in summer: implications in nutrient dynamics. Cont Shelf Res 16:1561-1590

Gong GC, Wen YH, Wang BW, Liu GJ (2003) Seasonal variation of chlorophyll a concentration, primary production and environmental conditions in the subtropical East China Sea. Deep-Sea Res II 50:1219-1236

Guo Y, Yang Z (1992) Seasonal variation of phytoplankton abundance in the Changjiang estuary. Stud Mar Sin 33: 167-189

Hamm CE, Merkel R, Springer O, Jurkojc P, Maier C, Prechtel K, Smetacek V (2003) Architecture and material properties of diatom shells provide effective mechanical protection. Nature 421:841-843

Harrison PJ, Hu MH, Yang YP, Lu X (1990) Phosphate limitation in estuarine and coastal waters of China. J Exp Mar Biol Ecol 140:79-87

He Q, Sun J, Luan Q, Yu Z (2009) Phytoplankton in Changjiang estuary and adjacent waters in winter. Mar Environ Sci 28:360-365

> Heil CA, Glibert PM, Fan C (2005) Prorocentrum minimum (Pavillard) Schiller: a review of a harmful algal bloom species of growing worldwide importance. Harmful Algae 4:449-470

Heiskanen AS (1993) Mass encystment and sinking of dinoflagellates during a spring bloom. Mar Biol 116: 161-167

Heiskanen AS, Kononen K (1994) Sedimentation of vernal and late summer phytoplankton communities in the coastal Baltic Sea. Arch Hydrobiol 131:175-198

> Hobson LA, McQuoid MR (1997) Temporal variations among planktonic diatom assemblages in a turbulent environment of the southern Strait of Georgia, British Columbia, Canada. Mar Ecol Prog Ser 150:263-274

> Huang B, Ou L, Hong H, Luo H, Wang D (2005) Bioavailability of dissolved organic phosphorus compounds to typical harmful dinoflagellate Prorocentrum donghaiense Lu. Mar Pollut Bull 51:838-844

> Huang B, Ou L, Wang X, Huo W and others (2007) Alkaline phosphatase activity of phytoplankton in East China Sea coastal waters with frequent harmful algal bloom occurrences. Aquat Microb Ecol 49:195-206

Juhl AR, Latz MI (2002) Mechanism of fluid-shear-induced inhibition of population growth in a red-tide dinoflagellate. J Phycol 38:683-694 
Juhl AR, Velazquez V, Latz MI (2000) Effect of growth conditions on flow-induced inhibition of population growth of a red-tide dinoflagellate. Limnol Oceanogr 45:905-915

Lee Chen YL (2000) Comparisons of primary productivity and phytoplankton size structure in the marginal regions of southern East China Sea. Cont Shelf Res 20:437-458

Li J, Glibert PM, Zhou M, Lu S, Lu D (2009) Relationships between nitrogen and phosphorus forms and ratios and the development of dinoflagellate blooms in the East China Sea. Mar Ecol Prog Ser 383:11-26

Li M, Xu K, Watanabe M, Chen Z (2007) Long-term variations in dissolved silicate, nitrogen, and phosphorus flux from the Yangtze River into the East China Sea and impacts on estuarine ecosystem. Estuar Coast Shelf Sci 71:3-12

Li RX, Mao XH (1985) Dinoflagellates in the continental shelf of the East China Sea. Donghai Mar Sci 3:41-55

> Lignell R, Kaitala S, Kuosa H (1992) Factors controlling phyto- and bacterioplankton in late spring on a salinity gradient in the northern Baltic. Mar Ecol Prog Ser 84: 121-131

Lin J (1995) Diversity study of planktonic dinoflagellates in China Seas. Chin Biodivers 3:187-194

> Lu DD, Goebel J, Qi YZ, Zou JZ, Han XT, Gao YH, Li YG (2005) Morphological and genetic study of Prorocentrum donghaiense Lu from the East China Sea, and comparison with some related Prorocentrum species. Harmful Algae 4:493-505

Luan QS, Sun J, Song SQ, Shen ZL (2008) Phytoplankton assemblage in Changjiang estuary and its adjacent waters in autumn, 2004. Adv Mar Sci 26:364-371

Margalef R (1978) Life-forms of phytoplankton as survival alternatives in an unstable environment. Oceanol Acta 1: 493-509

McQuoid MR, Nordberg K (2003) The diatom Paralia sulcata as an environmental indicator species in coastal sediments. Estuar Coast Shelf Sci 56:339-354

Pai SC, Tsau YJ, Yang TI (2001) pH and buffering capacity problems involved in the determination of ammonia in saline water using the indophenol blue spectrophotometric method. Anal Chim Acta 434:209-216

> Passow U (1991) Species-specific sedimentation and sinking velocities of diatoms. Mar Biol 108:449-455

Pollingher U, Zemel E (1981) In situ and experimental evidence of the influence of turbulence on cell division processes of Peridinium cinctum forma westii (Lemm.) Lefèvre. Br J Pharmacol 16:281-287

Qian SB, Chen GW (1986) A comprehensive study in Changjiang estuary and adjacent water of Cheju island: I. Phytoplankton community. J Ocean Univ Qingdao 16: 26-55

> Resende P, Azeiteiro U, Pereira MJ (2005) Diatom ecological preferences in a shallow temperate estuary (Ria de Aveiro, Western Portugal). Hydrobiologia 544:77-88

Riegman R, Colijn F, Malschaert J, Kloosterhuis H, Cadée G (1990) Assessment of growth rate limiting nutrients in the North Sea by the use of nutrient-uptake kinetics. J Sea Res 26:53-60

Rudek J, Paerl HW, Mallin MA, Bates PW (1991) Seasonal and hydrological control of phytoplankton nutrient limitation in the lower Neuse River Estuary, North Carolina. Mar Ecol Prog Ser 75:133-142

Shen L, Xu H, Guo X, Li M (2011) Characteristics of largescale harmful algal blooms (HABs) in the Yangtze River estuary and the adjacent East China Sea (ECS) from 2000 to 2010. J Environ Protect 2:1285-1294
Shen Z, Zhou S, Pei S (2008) Transfer and transport of phosphorus and silica in the turbidity maximum zone of the Changjiang estuary. Estuar Coast Shelf Sci 78:481-492

Simpson J, Hunter J (1974) Fronts in the Irish Sea. Nature 250:404-406

Smayda TJ (1997) Harmful algal blooms: their ecophysiology and general relevance to phytoplankton blooms in the sea. Limnol Oceanogr 42:1137-1153

Smayda TJ, Reynolds CS (2003) Strategies of marine dinoflagellate survival and some rules of assembly. J Sea Res 49:95-106

Stoecker DK (1999) Mixotrophy among dinoflagellates. J Eukaryot Microbiol 46:397-401

> Sullivan JM, Swift E, Donaghay PL, Rines JE (2003) Smallscale turbulence affects the division rate and morphology of two red-tide dinoflagellates. Harmful Algae 2: 183-199

Sun J, Liu DY (2004) The application of diversity indices in marine phytoplankton studies. Acta Oceanol Sin 26: $62-75$

Sun J, Song SQ (2009) Phytoplankton growth and microzooplankton herbivory during the spring phytoplankton bloom period in the East China Sea. Acta Ecol Sin 29: 6429-6438

Sun J, Liu DY, Wang ZL, Shi XY, Li RX, Zhu MY (2003) Microzooplankton herbivory during red tide-frequentoccurrence period in spring in the East China Sea. Yingyong Shengtai Xuebao 14:1073-1080 (in Chinese with English abstract)

Sun J, Song SQ, Wang D, Xu ZL (2007) Estimating Calanus sinicus grazing on phytoplankton and microzooplankton. Acta Ecol Sin 27:3302-3315

> Tang DL, Di BP, Wei GF, Ni IH, Wang SF (2006) Spatial, seasonal and species variations of harmful algal blooms in the South Yellow Sea and East China Sea. Hydrobiologia 568:245-253

Thomas WH, Gibson CH (1990) Quantified small-scale turbulence inhibits a red tide dinoflagellate, Gonyaulax polyedra Stein. Deep-Sea Res I 37:1583-1593

> Thomas WH, Vernet M, Gibson CH (1995) Effects of smallscale turbulence on photosynthesis, pigmentation, cell division, and cell size in the marine dinoflagellate, Gonyaulax polyedra. J Phycol 31:50-59

Turner RE, Rabalais NN, Nan ZZ (1990) Phytoplankton biomass, production and growth limitations on the Huanghe (Yellow River) continental shelf. Cont Shelf Res 10: 545-571

Utermöhl H (1958) Zur Vervollkommnung der quantitativen Phytoplankton-Methodik. Mitt Int Ver Theor Angew Limnol 9:1-38

> Wang BD, Wang XL, Zhan R (2003) Nutrient conditions in the Yellow Sea and the East China Sea. Estuar Coast Shelf Sci 58:127-136

Wang J (2002) Phytoplankton communities in three distinct ecotypes of the Changjiang Estuary. J Ocean Univ Qingdao 32:422-428

Wang J, Huang X (2003) Ecological characteristics of Prorocentrum dentatum and the cause of harmful algal bloom formation in China. Yingyong Shengtai Xuebao 14: 1065-1069 (in Chinese with English abstract)

Wang ZL, Li RX, Zhu MY, Chen BZ, Hao YJ (2006) Study on population growth processes and interspecific competition of Prorocentrum donghaiense and Skeletonema costatum in semi-continuous dilution experiments. Adv Mar Sci 24:496-503 
Welschmeyer NA (1994) Fluorometric analysis of chlorophyll- $a$ in the presence of chlorophyll- $b$ and pheopigments. Limnol Oceanogr 39:1985-1992

Wong GTF, Gong GC, Liu KK, Pai SC (1998) 'Excess nitrate' in the East China Sea. Estuar Coast Shelf Sci 46:411-418

Yanagi T, Takahashi S (1993) Seasonal variation of circulations in the East China Sea and the Yellow Sea. J Oceanogr 49:503-520

Yin K, Qian PY, Chen JC, Hsieh DPH, Harrison PJ (2000) Dynamics of nutrients and phytoplankton biomass in the Pearl River estuary and adjacent waters of Hong Kong during summer: preliminary evidence for phosphorus and silicon limitation. Mar Ecol Prog Ser 194:295-305

Yin KD, Song XX, Sun J, Wu M (2004) Potential P limitation

Editorial responsibility: Steven Lohrenz,

New Bedford, Massachusetts, USA leads to excess $\mathrm{N}$ in the Pearl River estuarine coastal plume. Cont Shelf Res 24:1895-1907

Zhao R, Sun J, Bai J (2010) Phytoplankton assemblages in Yangtze River estuary and its adjacent water in autumn, 2006. Mark Sci 34:32-39

Zhu G, Xu W, Zhu D, Shi Q, Zhang J (2003) Distribution of phytoplankton and water dynamical environmental factors in high red tide occurrence area of Changjiang River estuary. Yingyong Shengtai Xuebao 14:1135-1139 (in Chinese with English abstract)

Zhu ZY, Ng WM, Liu SM, Zhang J, Chen JC, Wu Y (2009) Estuarine phytoplankton dynamics and shift of limiting factors: a study in the Changjiang (Yangtze River) Estuary and adjacent area. Estuar Coast Shelf Sci 84:393-401

Submitted: September 10, 2013; Accepted: July 16, 2014

Proofs received from author(s): October 17, 2014 